\title{
肝炎括よび肝硬变症における免疫細胞化学的検討*
}

藤中 新 生 ${ }^{* *}$

\section{綨 曹}

肝炎の慢性化に自己免疫機転が関与しているか どらか，むし関与しているとすればいかなる形で 関与しているかという問題に関しては, 多数の研 究結果が報告されてはいるが，いまだ解決をみて いない.

Witebsky') は免度血清学的見地から, 自己免度 疾患であることの証明として次の条件をあげてい る. 1) 体温下で作用する遊離の循環抗体を直接 証明するか，細胞鉤着性抗体を間接的な方法で証 明する．2）このような抗体と特異的に反応する 抗原を証明する，3）このような抗原を用いて実 験動物に抗体の産生を証明する，4）この抗原で 感作された実験動物組織にヒトの疾患と同様の組 織学的変化を闰一の臟器に証明する.これらの観 点から肝疾患の病態を把握せんとして，いろいろ の研究が行なわれておりここと肝疾患のさいの 肝組織と反応する血中抗体の存在は1933 年に Hughes ${ }^{2)}$ が重症黄熱病で報告して以来, 補体結 合反応 ${ }^{8-12)}$, 沈降反応 ${ }^{13)}$, Ouchterlony法 ${ }^{14)}$, 感 作血球またはコロジゥム凝集反応と螢光抗体間接 法 ${ }^{15}{ }^{16)}$, 感作血球凝集反応之補体結合反応 ${ }^{17)}$ ，抗 グロブリン消費試験 ${ }^{18)}$, Prausnitz-Küstner 法 ${ }^{199}$, Schultz-Dale 法20)，䖝光抗体間接法 ${ }^{21 ~ 26)}$ などに よつて証明されている. 上田ら ${ }^{27}$ は肝疾患時の抗 肝抗体はグリソン䩵の細胞浸潤や線稚化等となん らかの関連をるつて血中に出現するものと推測し ているが, 肝機能障害の程度, 肝病変の進展とは 無関係で, 同一症例の経過中の抗肝抗体の出没は

* Immunocytochemical Investigation of Hepatitis and Hepatic Cirrhosis. 要旨は第 7 回日本消化器病学会秋季大 会, 日本消化器病学会第 52 回粉会, 第 3 回世界消化器病会 議にて発表した.

** Y. Fujinaka : 新沮大学木下内科 (指導; 木下康民教授).
臨床像の推移と関連性がないので，血中抗体の存 在は肝病変の成因に重要な役割を演じているとは 結論しがたく，むしろ二次性の因子であるとのべ ている、一方,長島副はウイルス性肝炎でポール・ バンネル反応凝集価の上舁, 自己赤血球に対する 不完全抗体の出現を認めているが，肝自己抗体の 高値を示す例でも肝組織像に病変の少ない症例の あることから，肝細胞の変化と自己抗原性の獲得 との間にはかなりの坊ることを予想してい る. しかし肝自己抗体の認められた例では症状の 改善が少ないので, 肝自己抗体は肝炎の経過にな んらかの修飾を与えるものと推測している. 松 橋29》によると血中抗体は生体の破壊産物と結合し て血中からこれらの物質の除去を行ならと考光， このよらな機構を immunoclearance と命名して いる. 血中に抗肝抗体を証明したというこれらの 報告は, 急性あるいは慢性の肝疾患に免疫反応が 䓯起されていることを暗示はしているが，肝疾患 の病態にいかなる役割を演じているかの点では十 分解明されていないことを意味する. 一方，これ らの報告の大部分は抗原として同種または異種の 肝組織を用いておう，また in vitro での成績の ため検出された血中抗体は真の意味の自己抗体と はいえない，それには抗原として自己の肝組織を 用いる必要があり，また抗原と自己抗体との結合 物または細胞鈎着性自己抗体を病肝の壊死巣内に in vivo で証明しなければならないが，かかる報 告は乏しい.

私は肝咨の慢性化和よび肝硬変の成立に対する 自己兔疫機転の関与と, ステロイドホルモンの自 己免度機転に対する効果を検討する目的で, Coons の䖝光抗体法の変法を用い, 四塩化炭素投 与ダイコクネズミとステロイドホルモン併用ダイ コクネズミの血清および肝について免疫細胞化学 


$$
8: 310
$$

的検討を行なつた．また，ウイルス性肝炎の進展 過程に対する自己免疫機転の関与を臨床の面上り 把握すべく，ヒトの肝疾患の血清および肝につい ても免疫細胞化学的検討を行ない，いずれの場合 においても，とくに障害肝細胞に抗原抗体結合物 または細胞鉤着性抗体の検索につとめた，その結 果，若干の知見をえたのでここに報告する.

\section{実験材料と方法}

\section{I. 実医娌物}

A）四監化㞸素障害肝における抗原抗体結合物または 細胞鉤着性抗体の検討

実験前 $1 \sim 2$ 週間オリエンタル製固形飼料と甘藍また は水を自由に捠取せしめて飼育した体重 80 250g の雌 性ダイコクネズミ178 匹を次の9群に分類した。なお， 実験期間中も同一の飼料をるつて飼育した。

四塩化炭素単独投与群は 2 週か59週まで每週，その 他の群は 4 週と 8 週に，エーテル麻醉下で開腹開胸後心 朠穿刺により採血致死せしめ，その肝について検 討し た.

1) 四塩化炭素週 2 回単独投与群 $(39 匹)$

2）四塩化炭素およびプレドニソロン週 2 回 投与群 (16 匹)

3）四塩化炭素週 2 回およびプレドニンロン毎日投与 群 (15 匹)

4）プレドニソロン週 2 回投与群 (21 匹)

5）ブレドニソロン毎日投与群 (21 匹)

6) オリーブ油週 2 回投与群 $(20$ 匹)

7）オリーブ油週 2 回および生理的食塩水毎日投与群 (20 匹)

8）オリーブ油および生理的食塩水週 2 回投与群 (20 匹)

9) エーテル麻醉群（6匹）

B）四塩化炭素障害肝に括ける抗原抗体結合物または 細胞鈎着性抗体と血中抗肝抗体の検討

四監化炭素週 2 回単独投与ダイコクネズミ41 匹を次 の 8 群に分類し 2 週から 9 週まで毎週，エーテル麻醉下 で開腹開胸後心荿穿刺により採血致死せしめ，その肝之 血液について検討した. 末処置群 10 匹については 4 週 と 8 週に同棣な方法で検討した.

1) 投与 2 週間の群 ( $3 匹)$

2) 投与 3 週間の群 (3匹)
8 巻 4 号 (1967)

3) 投与 4 週間の群 (11 匹)

4) 投与 5 週間の群 ( 3 匹)

5) 投与 6 週間の群 $(3 匹)$

6) 投与 7 週間の群 ( 3 匹)

7) 投与 8 週間の群 $(10$ 匹)

8) 投与 9 週間の群 ( 5 匹)

9) 未処盾群 (10 匹)

C) 四塩化炭素 1 回注射後の血中抗肝抗体の検討 ダイコクネズミ32 匹を次の6群に分類し, 四塩化炭 素 1 回筋注後 1 日から5 日まで每日，エーテル麻醉下て 開腹開胸後心臓穿刺によりえた血液について湌討した。

1) 投与後 1 日の群 ( 5 匹)

2) 投与後 2 日の群 ( 5 匹)

3) 投与後 3 日の群 ( 5 匹)

4) 投与後 4 日の群 ( 4 匹)

5) 投与後 5 日の群 $(3 匹)$

6) 末処置群 (10 匹)

II. 四塩化炭素とプレドニソロン

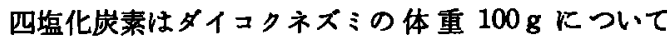
$0.075 \mathrm{cc}$ を等量のオリーブ油に混じて大眼に筋注した。 ブレドニンロンは体重 $100 \mathrm{~g}$ について $0.05 \mathrm{mg}$ を生食 水 $0.15 \mathrm{cc}$ に溶解して大眼に筋注した. ブレドニソロン 併用群では四塩化炭素とプレドニンロンの筋注を左右の 大跟に別々に行なつた。

III. 扱つた患者血简およひ肝

入院中の肝疾患ならびに対照疾患 68 名で臨床症状， 検㚗所見 (血清タンパク像は滤紙電気泳動法, 肝機能検 查は BSP 30 分值，TTT，ZTT， CCLF による望質反 応，血清トランスフミナーゼ活性)，組儎学的所見 等を 綜合して診断の確実な症例を対象とした，その疾患の内 訳は，伝染性肝炎 7 例，血清肝炎 8 例，慢性肝炎 15 例， 肝硬変 7 例，発作性夜間血色素尿症 1 例，サルコイドー シス 5 例，SLE 1例，梅毒および 性クロッショーカー 1 例, 胃潰港 2 例, 胃癌 19 例の計 68 例である.

\section{IV. 光抗体法}

䖝光抗体法は Coons 5 ${ }^{80}$ )の方法の变法を用いた．抗 原と自己抗体との結合物または細胞鈎着性自己抗体の検 出のためには，ダイコクネズミの場合は切除肝につい て，ヒトの場合は生検肝または切除肝について䖝光抗体 直接法で倹討した．流血中の抗肝抗体の検出のために は，ダイコクネスミの場合は心贜穿刺により，ヒ卜の場 合は肘静脈より探血した血清について管光抗体間接法で 
検討した.

1) 篮光抗体直接法

A）標本の作製：ダイコクネズミの摘出肝は可及的速 やか炕約 $10 \mathrm{~mm}$ 四方のブロックとし，ドライアイスフ セトンで $-74^{\circ} \mathrm{C}$ にあらかじめ冷却されたノーマルへキ サンの中に約 $30 \sim 60$ 秒間漫して凍結後, サランラップ とバラフィルムで二重に包んで $-20^{\circ} \mathrm{C}$ のストッカー中 で保存した. ヒトの肝は生険後ただちに約 $10 \mathrm{~mm}$ 四方 のアルミ䇴に入れた卵白に包埋後，切除肝はただちに同 様操作で東結保存した. 生検肝の一部については 95\%

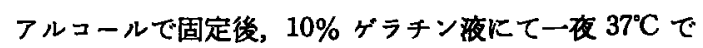
包埋後倲結を行ないストッカー中で保存した. 凍結肝ブ ロックは用時ストッカーの中から取り出し, $-15^{\circ} \mathrm{C} の ク$ リオスタット中で少量の $\mathrm{pH} 7.2$ の燐酸縓衙生食液で 金属性ブロックに涷結, ミノー型ミクロトームで厚さ $4 \mu$ の切片とし，良質のA級無䖝光载物ガラス $(76 \times 26$ $\times 1 \mathrm{~mm}$ )にのせて指の先で温めてはりつけた後, ただち に扇風機で風乾，室温で特級アセトンで 5 分間固定挠， 同棣風乾した，一部の切片は未固定のまま使用した。

B）染色方法：上述の載物ガラス上のフセトン固定切 片は $\mathrm{pH} 7.2$ の燐酸緩衝生食液で軽く洗浄後風乾して から, 未固定切片はそのままで $\mathrm{pH} 7.2$ の燐酸楥衖生 食液を毛細管ビペットで2〜3滴重ねた後, さらに䖝光 抗体液を同量滴下し，蒸発を防ぐために湿つた渚紙を底 に敷いた有蓋シャーレの中に入れ，37C 30 分間反応さ せた. 次いで載物ガラスをシャーレより取り出し， $\mathrm{pH}$ 7.2 の燐酸緩䈟生食液を載物ガラス上に十分に盛り，15 分間に数回同液を盛りな括して十分洗浄後，扇風機で風 乾してから $90 \%$ グリセロール燐酸緩衝生食液を滴下 し,カバーダラスで被つた. $\mathrm{pH} 7.2$ の燐酸綏衙生食液 の組成恃食塩 $12 \mathrm{~g}, \mathrm{NaH}_{2} \mathrm{PO}_{4} \cdot \mathrm{H}_{2} \mathrm{O} 0.6 \mathrm{~g}, \mathrm{Na}_{2} \mathrm{HPO}_{4}$. $7 \mathrm{H}_{2} \mathrm{O} 2.85 \mathrm{~g}$, 蒸溜水 $1.5 \mathrm{l}$ であり, 冷臟庫に保存した. 90\%グリセロール橉酸緩衙生食液は特級グリセロール と上述の $\mathrm{pH} 7.2$ の燐酸緩衙生食液を扣の扰の 9 対 1 の 割で混合したものである、䖝光抗体液はダイコクネズミ の場合, シルバーナ社製の fluorescein isothiocyanate 摽識 rabbit anti rat globulin globulin (Lot No. 092864 D）を使用した。 ヒトの場合は東大伝研試験製造室で作 成した抗ヒト $\gamma$-ダロブリン・F.I.T.C.・ラヘル・鬼 $\gamma$ グロブリンを使用した.

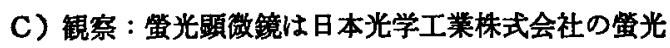
顕徽鏡装固, または千代田管光光源と暗視野䫒微鏡装置 でUV 系または BV 系励起フィルターを用いて観察し
た. 写真撮影には Kodak TRI-X Pan (ASA 400) と Anscochrome (ASA 200) を使用し, 露出時間はそれぞ れ 1 分と $2 \sim 3$ 分である.

D）非特異的染色因子の除去

1) マウス肝粉末の作製法

Coons, Leduc, Connolly 5 わち新鮮なマウス肝 $25 \mathrm{~g}$ を鍁で細切後, 等量の生食水 を加え，周囲に氷をつめたホモブレンダーで乳绪を作 る.この乳刜をビーカーに入れ，挸找しつつ4倍量の特 般アセトンを加えて2 3 分静固してから上清夜を静か に唅て, 沈渣を $2,000 \mathrm{rpm} 30$ 分間遠心し，これを数回 生食水で洗浄遠心し, 上清液中に血液の色調がなくなる まで絽り返した，次にこの沈澱に等量の生食水を加え， 摜拌しながら 4 倍量の特級てセトンを加え 3 分放眉した のち上清を捨て，これに 4 倍量の特級アセトンを加えて 慜濁液を作りBuchner 淔斗で吸引後, 室内に放置, $37^{\circ} \mathrm{C}$ 一夜乾燥後, 密栓をして $4^{\circ} \mathrm{C} て ゙$ 貯えた。

2) 四收法

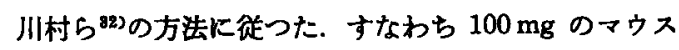
肝粉末を試験管にとり，2 cc の生食水を加えて室温放置 後, $12,000 \mathrm{rpm}$ で 30 分間遠心し，沈渣に䖝光抗体液 $1 \mathrm{cc}$ を加えて拱䢁し，室温に 1 時間放置してのち 12000 rpm 30 分間遠心してえた上清に, 上述と同様にあらか じめ生食水で洗浄した $50 \mathrm{mg}$ のマウス肝粉末を加え， 室温に 1 時間放值後 $12000 \mathrm{rpm}$ で 30 分間遠心してえ た上清を染色に用いた.

E) 対照染色：䖝光が認められた場合，これが免度学 的に特異的なるのかどうかを確めるために, Coons ら ${ }^{\text {so), }}$ Freedman 588) の方法に徒つた.

1）未漂識の抗体液で切片を前処直後，螢光抗体液で 染色した. 本研究では䖝光は認められなかつた。

2）ヒト $\gamma$ グロブリンと抗ヒト $\gamma$ グロブリン・F.I. T.C.・ラベル鬼 $r$ グロブリン，ダイコクネズミダロブ リンと抗ダイコクネズミダロブリン・F.I.T.C.・ラン ル鬼グロブリンをあらかじめ試験管内で作用させた後， 肝切片を染色した. 本研究では䖝光は認められなかつ た.

3）種族特異性を検する目的で，特異螢光陽性例のブ ロックからえたダイコクネズミ肝切片を抗ヒト ブリン・F.I.T.C.・ラベル鬼 $r$ グロブリンで染色した. 本研究では螢光は認められなかつた。

F) Elution Procedure: Freedman 5 53 の方法に従 い, 特異䖝光として認められたグロブリンが抗体性か否 
かを検した，すなおち，特異䖝光陽性例のブロックから 之た肝切片を $\mathrm{pH} 7.2$ の燐酸緩衝生食液で洗浄後, $\mathrm{pH}$ 3.3 のクエン酸緩衝液で $5 \sim 30$ 分間室温処理後, $\mathrm{pH} 7.2$ の燐酸緩衝生食液で洗い螢光抗体直接法を実施した. そ の結果, elution 5 分では䖝光の減弱は認められないが, 15 分で著明な減弱を, 20 分で完全な消失を認めたので, 特異䖝光として認められたグロブリンは抗体性のグロブ リンと推定した. 臨床例にはこの操作は実施しなかつ

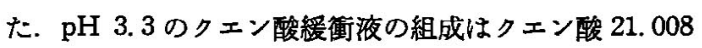
$\mathrm{g}$ を $1 \mathrm{~N}-\mathrm{NaOH} 200 \mathrm{cc}$ にとかし水 $1000 \mathrm{cc}$ にすす て作つた $0.1 \mathrm{M}-ク エ ン$ 酸ソーダー $4.5 \mathrm{cc} に, 0.1 \mathrm{~N}-$ $\mathrm{HCl} 5.5 \mathrm{cc}$ を加えたものである.

\section{2) 螢光抗体間接法}

反応をらける肝組織としては，ダイコクネズミの場合 には組織学的に正常な同種ダイコクネズミの肝を，ヒト の場合には組織学的にも機能的にも異常のない切除肝を 材料として，クリオタットで $4 \mu$ の凍結切片とし未固 定のまま使用した. すなわち, 上述の肝切片に被検血清 を $37^{\circ} \mathrm{C} 30$ 分間作用させた後, $\mathrm{pH} 7.2$ の燐酸緩衝生 食液で 15 分間洗い, あらかじめマウス肝粉末で吸収を 行なつた螢光抗体液を $37^{\circ} \mathrm{C} 30$ 分間作用させ，次いで 再度 $\mathrm{pH} 7.2$ の燐酸緩衝生食液で 15 分間洗浄後扇風機 で風乾し，90\%グリセロール燐酸緩衝生食液を 滴下し カパーグラスで被い，䖝光頭微鏡で観察した．観察の方 法, 非特異的染色因子の除去, 奶照染色, elution procedure は直接法の場合に準じた.

V. 光学影微鏡による検査

ダイコクネズミおよびヒトの肝ブロックは䖝光抗体法 で検する一方，ヘマトキシリンエオジン (H-E) 染色, フザンマロリー (A-M) 染色, ズダンII染色む実施し た.

\section{VI. 肝病変と抗体との関係について}

肝病変の度合と細胞鉤着性抗体, 循環抗体との関係に ついても若干の検討を行なつた.

\section{結 果}

\section{I. 動 物 実 験}

A）光学顕微鏡による所見

実験 A), B) の四塩化炭素投与 4 週群と 8 週群にお いて，四塩化炭案単独投与ダイコクネズミ40 匹，扣よ びプレドニソロン併用ダイコクネズミ31匹, 合計 71 匹の光学顕微鏡による所見を比較検討してみると, 四塩 化炭素投与 4 週間では, 四塩化炭素単独投与群, プレド
8 巻 4 号 (1967)

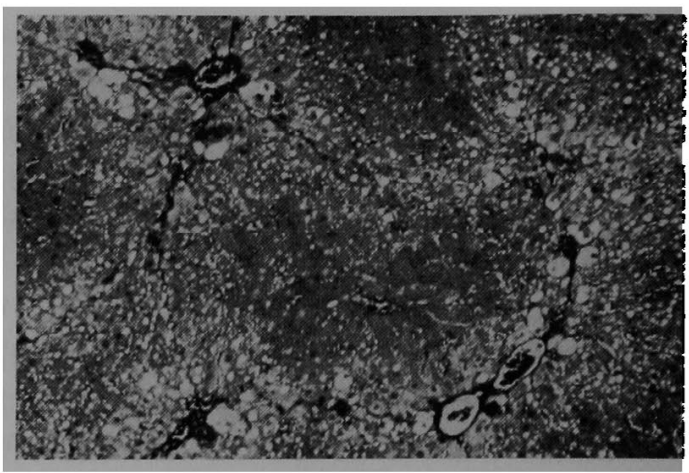

図 1. 四塩化炭甞投与 4 週 (A-M)

軽度の楾䊒增生があるが偽小葉形成はない。

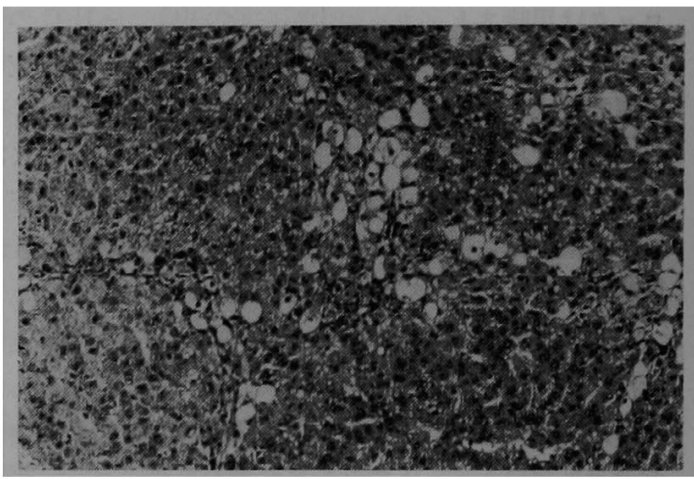

図 2. 四塩化炭素投与 4 週 (H-E)

肝細胞索の乱れ，胞助化が軽度にある。

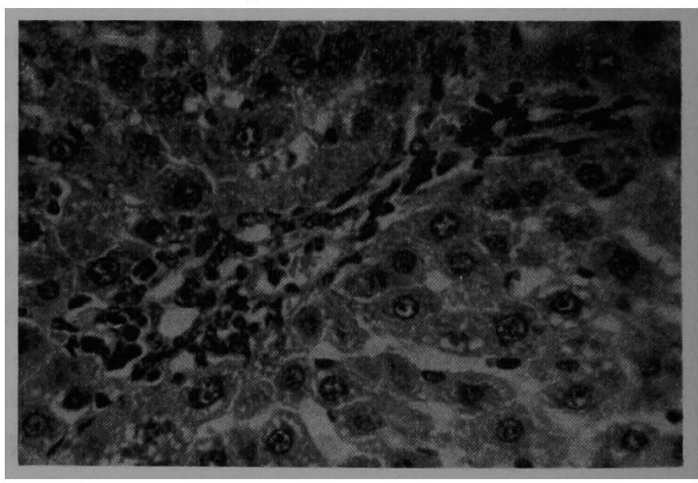

図 3. 四塩化炭素投与 4 週 (H-E)

肝細胞壊死，星細胞動只，細胞浸潤等が軽度

ニソロン毎日および間歇併用群の3 群とも線維增生は軽 度であり，偽小葉の形成はまだみられず(図 1), 肝細胞 索の乱れ, 脂肪化, 壊死, 星細胞の動員, 細胞浸潤等が 軽度ながらみられた（図 $2 ， 3$ ). 四塩化炭素投与 8 週間で は3群とも線維增生が高度となり, 偽小葉の形成があり 


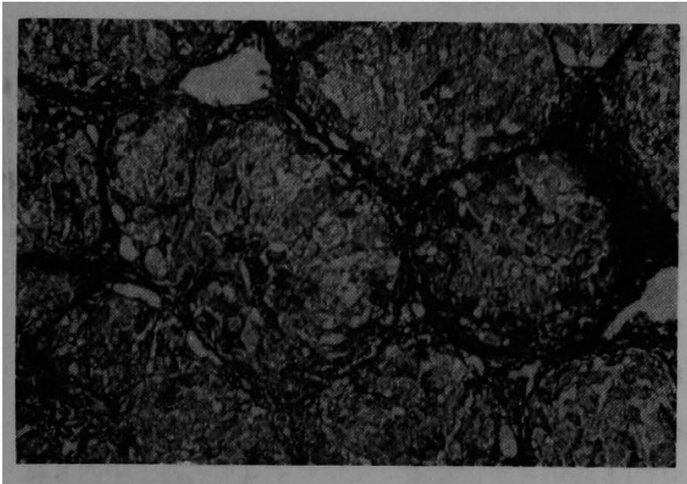

図 4. 四塩化炭素投与 8 远 (A-M) 高度の線維增生と傦小葉形成

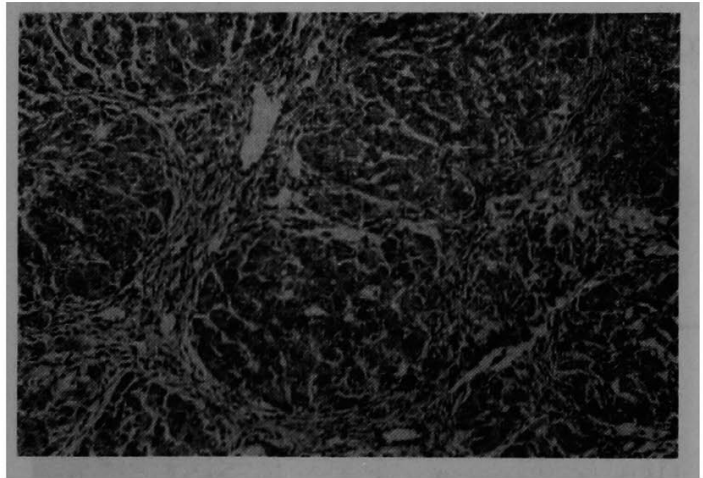

図 5. 四塩化宸素投与 8 週 (H-E) 著明な稩胞浸润

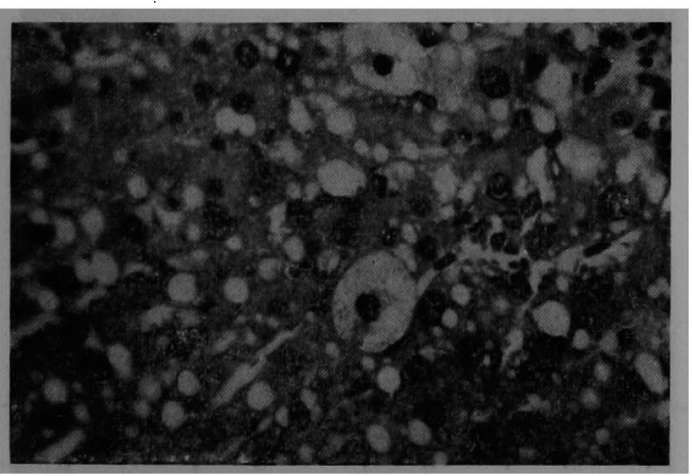

図 6. 四塩化炭素投与 8 週 (H-E) 肝細胞媴死，胞肪化等が高度

（図 4 ），肝細胞の壊死，脂肪化，細胞浸潤等が著明とな り (図 5,6)，小葉周辺部の肝細胞の切り崩し（図7）, 胆管の增生(図 8，9)，静脈腔の拡大等がみられた．偽 小葉形成を各群についてみると四塩化炭素単独投与群で は 18 匹中 7 匹, プレドニソロン毎日併用群と間影併用

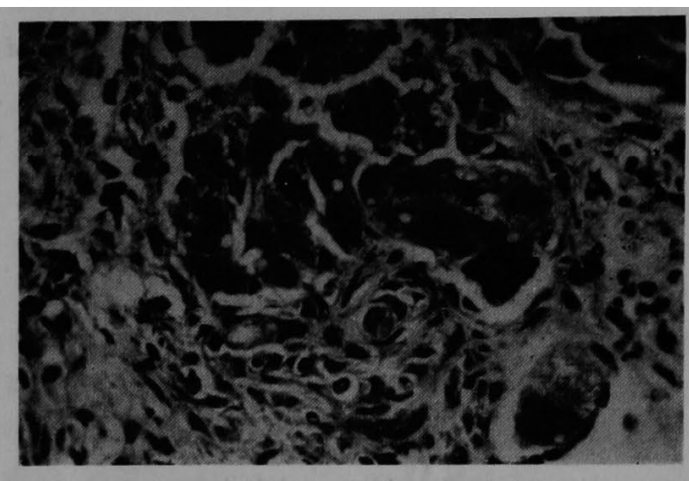

図 7. 四塩化炭委投与 8 週 $(\mathrm{H}-\mathrm{E})$ 小葉周辺部の肝稩胞の切り崩し現象

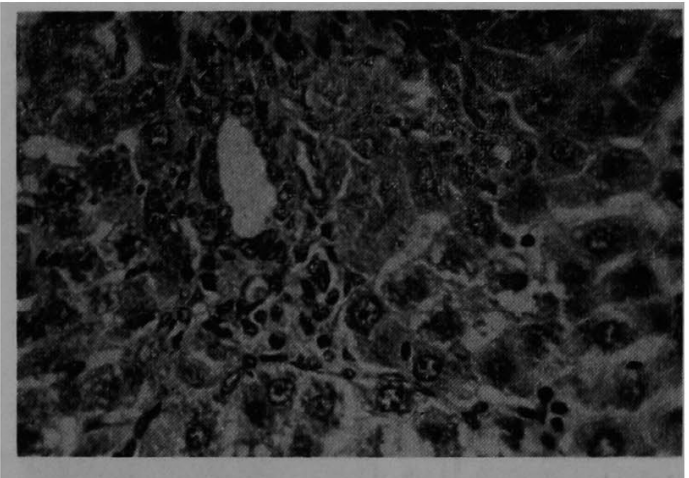

图 8. 四塩化炭素投与 8 飔 $(\mathrm{H}-\mathrm{E})$

胆管增生と細胞浸洞を伴なつた小莱内線維伸展

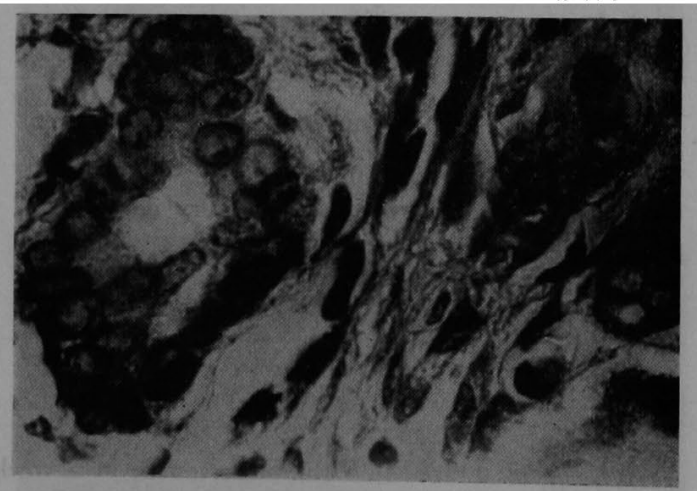

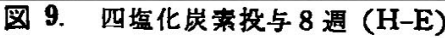
間貿での胆管の增生

群ではいずれも 8 匹中 3 匹ずつであつた(表 1 ).

B）䖝光抗体法による所見

1）実験 A）に㧍ける成績は表 2 のごとくで線維增 生が軽度にみられる4 週で障害された肝細胞に抗体性と 推定されろグロプリンを認めるむのは，四塩化孷素単独 
表 1. Light microscopic study of $\mathrm{CCl}_{4}$ induced hepatic damages in rats

\begin{tabular}{|c|c|c|c|c|c|}
\hline $\begin{array}{l}\text { Number } \\
\text { of Rat. }\end{array}$ & Treatment & $\begin{array}{l}\text { Treatment } \\
\text { weeks }\end{array}$ & $\begin{array}{l}\text { Fibrous } \\
\text { proliferation }\end{array}$ & $\begin{array}{l}\text { Pseudobule } \\
\text { formation }\end{array}$ & $\begin{array}{l}\text { Necrosis of } \\
\text { hepatic cell }\end{array}$ \\
\hline 22 & $\mathrm{CCl}_{4}$ (twice in a weeks) & 4 & + & - & + \\
\hline 8 & $\begin{array}{l}\mathrm{CCl}_{4} \text { (twice in a week) with } \\
\text { prednisolone (every day) }\end{array}$ & 4 & + & - & $\underset{:}{+}$ \\
\hline 7 & $\begin{array}{l}\mathrm{CCl}_{4} \text { with prednisolone } \\
\text { (twice in a week) }\end{array}$ & 4 & + & - & + \\
\hline 18 & $\mathrm{CCl}_{4}$ (twice in a week) & 8 & 卅 & $7 / 18$ & 册 \\
\hline 8 & $\begin{array}{c}\mathrm{CCl}_{4} \text { (twice in a week) with } \\
\text { prednisolone (every day) }\end{array}$ & 8 & \# & $3 / 8$ & 册 \\
\hline 8 & $\begin{array}{l}\mathrm{CCl}_{4} \text { with proednisolone } \\
\text { (twice in a week) }\end{array}$ & 8 & H & $3 / 8$ & 世 \\
\hline 71 & Total & & & & \\
\hline
\end{tabular}

表 2. Fluorescent microscopic study of $\mathrm{CCl}_{\text {, induced hepatic damages in rats }}$

\begin{tabular}{|c|c|c|c|c|c|c|}
\hline \multicolumn{2}{|c|}{$\begin{array}{l}\text { Number } \\
\text { of Rat. }\end{array}$} & \multirow{2}{*}{ Treatment } & \multirow{2}{*}{$\begin{array}{l}\text { Treatment } \\
\text { weeks }\end{array}$} & \multicolumn{3}{|c|}{$\begin{array}{l}\text { Number of rats showing localization } \\
\text { of "Localizing Antibody" in }\end{array}$} \\
\hline Total & & & & $\begin{array}{l}\text { Hepatic } \\
\text { cell }\end{array}$ & $\begin{array}{l}\text { Infiltrative } \\
\text { cell }=-1\end{array}$ & $\begin{array}{l}\text { Hepatic cell \& } \\
\text { infiltrative cell }\end{array}$ \\
\hline 39 & $\begin{array}{r}3 \\
3 \\
11 \\
3 \\
3 \\
3 \\
8 \\
5\end{array}$ & $\mathrm{CCl}_{4}$ (twice in a week) & $\begin{array}{l}2 \\
3 \\
4 \\
5 \\
6 \\
7 \\
8 \\
9\end{array}$ & $\begin{array}{l}0 \\
0 \\
1 \\
0 \\
0 \\
0 \\
1 \\
1\end{array}$ & $\begin{array}{l}0 \\
0 \\
0 \\
0 \\
0 \\
0 \\
1 \\
0\end{array}$ & $\begin{array}{l}0 \\
0 \\
0 \\
0 \\
0 \\
0 \\
0 \\
1 \\
0\end{array}$ \\
\hline 16 & $\begin{array}{l}8 \\
8\end{array}$ & $\mathrm{CCl}_{4}$ with prednisolone (twice in a week) & $\begin{array}{l}4 \\
8\end{array}$ & $\begin{array}{l}2 \\
0\end{array}$ & $\begin{array}{l}0 \\
2\end{array}$ & $\begin{array}{l}0 \\
1\end{array}$ \\
\hline 15 & $\begin{array}{l}7 \\
8\end{array}$ & $\begin{array}{l}\mathrm{CCl}_{4} \text { (twice in a week) } \\
\text { with prednisolone (every day) }\end{array}$ & $\begin{array}{l}4 \\
8\end{array}$ & $\begin{array}{l}3 \\
3\end{array}$ & $\begin{array}{l}0 \\
-1\end{array}$ & $\begin{array}{l}0 \\
0\end{array}$ \\
\hline 21 & $\begin{array}{l}11 \\
10\end{array}$ & Prednisolone (twice in a week) & $\begin{array}{l}4 \\
8\end{array}$ & $\begin{array}{l}\mathbf{0} \\
\mathbf{0}\end{array}$ & $\begin{array}{l}0 \\
0\end{array}$ & $\begin{array}{l}0 \\
0\end{array}$ \\
\hline 21 & $\begin{array}{l}11 \\
10\end{array}$ & Prednisolone (every day) & $\begin{array}{l}4 \\
8\end{array}$ & $\begin{array}{l}0 \\
0\end{array}$ & $\begin{array}{l}0 \\
0\end{array}$ & $\begin{array}{l}0 \\
0\end{array}$ \\
\hline 20 & $\begin{array}{l}10 \\
10 \\
\end{array}$ & Olive Oil (twice in a week) & $\begin{array}{l}4 \\
8\end{array}$ & $\begin{array}{l}0 \\
0\end{array}$ & $\begin{array}{l}0 \\
0\end{array}$ & $\begin{array}{l}0 \\
0\end{array}$ \\
\hline 20 & $\begin{array}{l}10 \\
10\end{array}$ & $\begin{array}{l}\text { Olive oil (twice in a week) } \\
\text { with saline (every day) }\end{array}$ & $\begin{array}{l}4 \\
8\end{array}$ & $\begin{array}{l}0 \\
0\end{array}$ & $\begin{array}{l}0 \\
0\end{array}$ & $\begin{array}{l}0 \\
0\end{array}$ \\
\hline 20 & $\begin{array}{l}10 \\
10\end{array}$ & Olive oil with saline (twice in a week) & $\begin{array}{l}4 \\
8\end{array}$ & $\begin{array}{ll}0 & \\
0 & \cdots\end{array}$ & $\begin{array}{l}0 \\
0\end{array}$ & $\begin{array}{l}0 \\
0\end{array}$ \\
\hline 6 & $\begin{array}{l}3 \\
3\end{array}$ & Ether anaesthesia & $\begin{array}{l}4 \\
8\end{array}$ & $\begin{array}{l}0 \\
0\end{array}$ & $\begin{array}{l}0 \\
0\end{array}$ & $\begin{array}{l}0 \\
0\end{array}$ \\
\hline 178 & & Total & & 11 & 4 & 2 \\
\hline
\end{tabular}

投与群 11 匹中 1 匹, プレドニソロン間歇併用群 8 匹中 2 匹，ブレドニソロン毎日併用群 7 匹中 3 匹にあり，偽
小葉形成がみられる 8 週で同様に障害された肝細胞に抗 体性と推定されるグロブリンを認めるむのは，四塩化宸 
素単独投与群 8 匹中 1 匹, プレドニソロン間歇併用群 8 匹中 0 匹,プレドニソロン毎日併用群 8 匹中 3 匹であり, 四塩化炭素単独投与 9 週群では 5 匹中 1 匹にあつた。 た，四塩化炭素投与 8 週群で間質の浸潤細胞に抗体性と 推定されるグロブリンを認めるむのは，四塩化炭素単独 投与群 8 匹中 1 匹, プレドニンロン間歇併用群 8 匹中 2 匹，プレドニソロン毎日併用群 8 匹中 1 匹であつた。 一 方, 間質の浸潤細胞之肝細胞の両者に抗体性之推定され るグロブリンを認めるものは, 四塩化炭素単独投与 8 週 群 8 匹中 1 匹, プレドニソロン間歌併用 8 週群 8 匹中 1 芯、プレドニソロン每日併用 8 週群 8 匹中0匹であつ た. しかし，2，3，5，6，7の各週では肝組織内に 抗体性と推定されるグロブリンの肝組織内での検出率を 四監化炭素単独投与群とプレドニソロン併用群とで比較 すると，ほぼ同率でいずれも低率であつた。

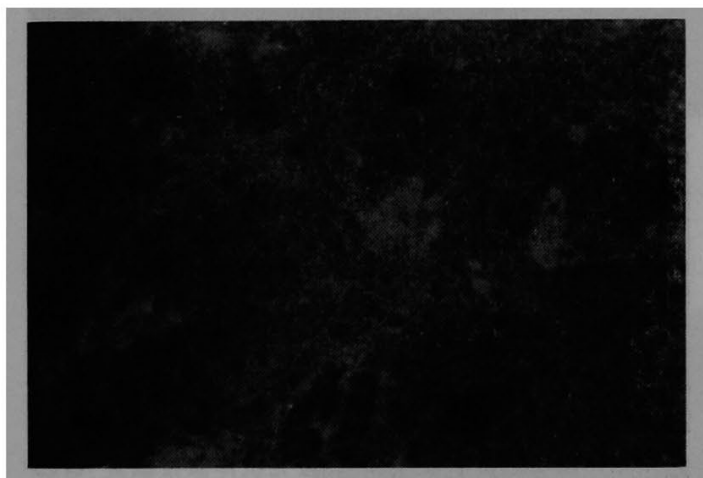

図 10. 四塩化炭案投与 4 週 (螢光抗体直接法). 自己 抗体と考えられるグロプリンの特巽螢光は小葉 内の肝細狍に認められる。

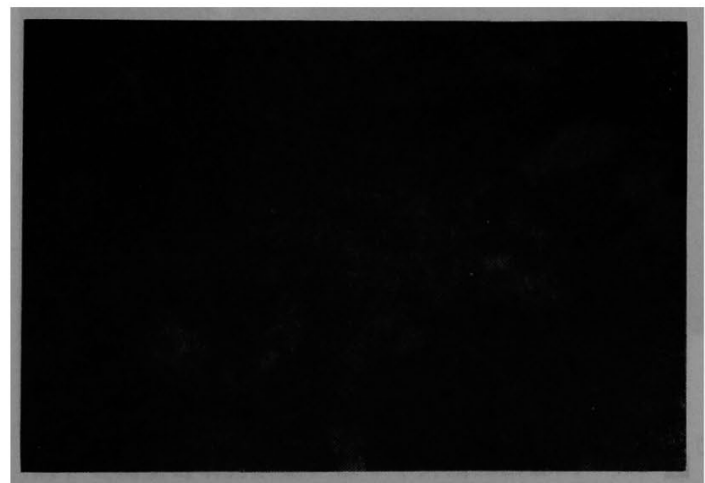

図 11. 四塩化炭者投与 4 週(螢光抗体直接法). 自己 抗体と考えられるグロブリンの特異螢光は小集 内の肝綀胞に認められる。
次に個々の例を示寸と，図 $10 ， 11$ は四塩化炭素単独 投与 4 週群の一例で, 肝細胞の細胞質にグロブリンを認 めた． 細胞質にグロブリンを認める肝細胞が小葉内で単 一にあるいは群をなして存在することは興味のある点で ある. 図 12,13 はプレドニソロン毎日併用 4 週群の 1 例で，限界板を構成する一部の肝細胞の細胞質にグロブ リンを認めた. 図 $14,15,16$ は四塩化炭素単独投与 8 週 群の 1 例で，線維性隔壁内の浸潤細胞にグロブリンを認 めた. 図 17,18 は四塩化炭素単独投与 8 週群の他の一 例で, 線維性隔壁内および小葉内の浸潤細胞とそれらに 近接した一個の肝細胞にグロブリンを認めた。 図 19,20 は四塩化炭素単独投与 8 週群の他の一例で, 線維性隔壁 内および小葉内の浸潤細胞と小葉内の単一の肝細胞にク ロブリンを認めた，図 21 は図 $17 １ 8$ と同例の他の小 䈎で, 線維性隔壁内の浸潤細胞, 限界板の一部の肝細胞

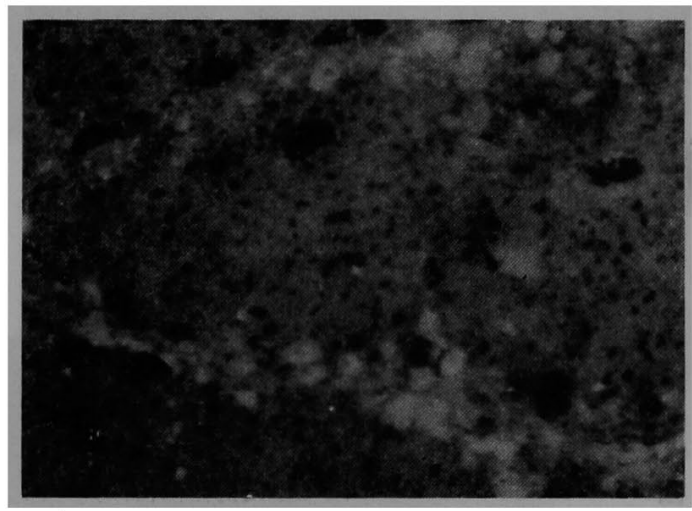

图 12. プレドニソロン毎日併用 4 週（螢光抗体直接 法). 自己抗体と考えられるグロブリンの特異 䖝光は限界板の一部の肝細胞に認められる。

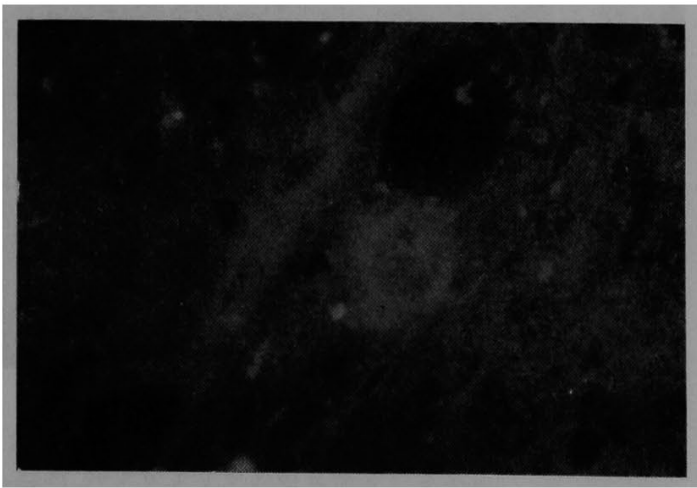

图 13. プレドニソロン毎日併用 4 週（螢光抗体直接 法). 图 12 の強拡大. 自己抗体と考えられる クロプリンの特異營光は限界板の肝細胞に㑇め られる。 


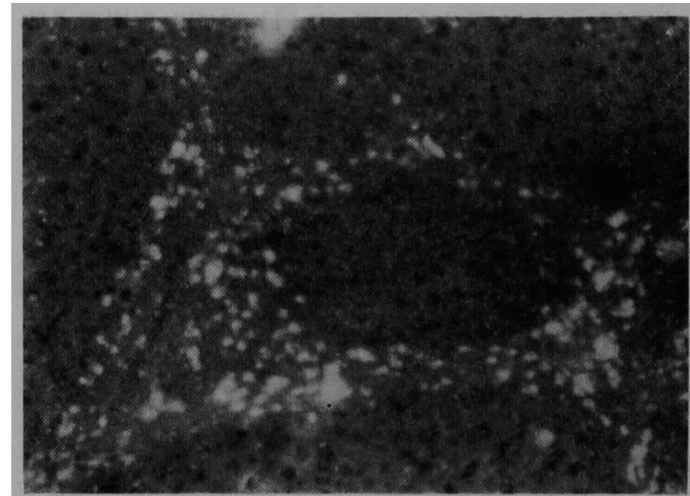

図 14. 四塩化岸案投与 8 週(螢光抗体直接法). 自己

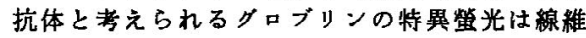
性隔壁内の浸潤細胞汇訆められる。

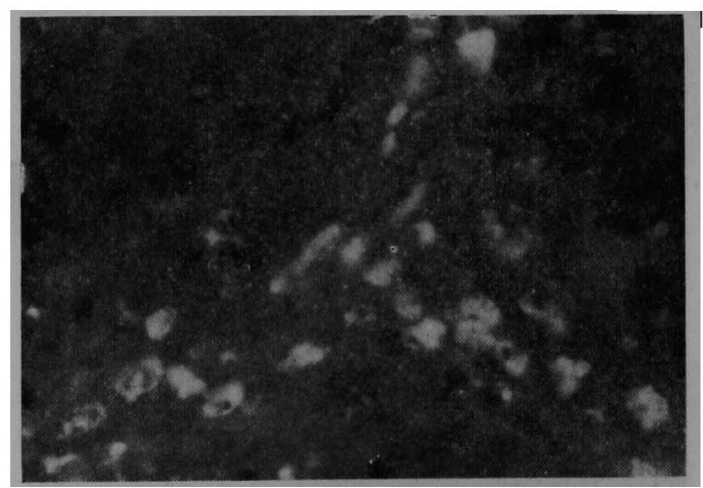

図 15. 四塩化炭素投与 8 週（管光抗体直接法），因 14 の強拡大

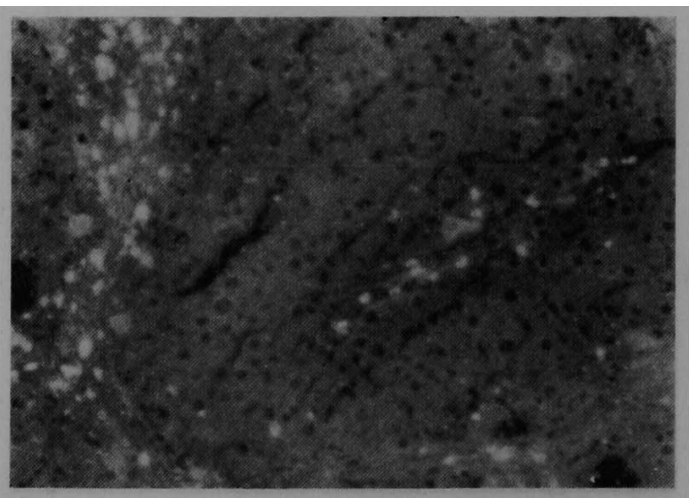

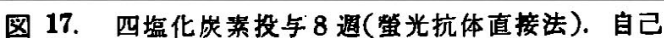
抗体と考えられるクロブリンの特異签光は線稚 性隔壁内および小菜内の浸潤勫胞とそれらに近 接した䀒細胞の 1 個に認められる。

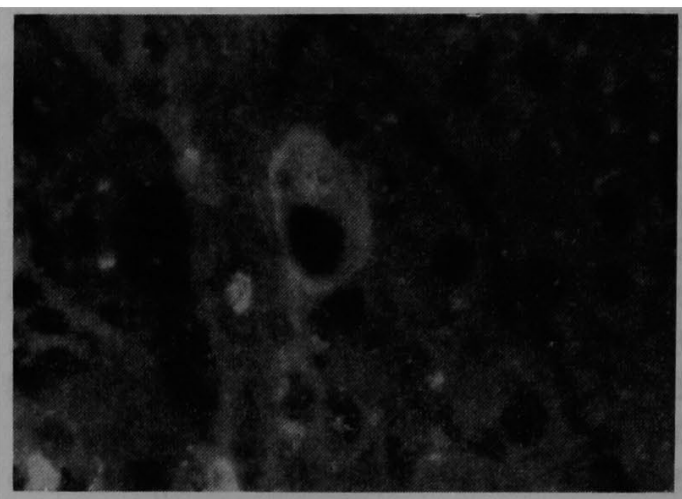

图 18. 四塩化岸素投与 8 週(螢光抗体直接法)自己抗 体と考えられるグロブリンの特異螢光は線維生 隔壁内の 2 個の浸洞細胞および小葉内の 1 個の 漫潤細胞と限界板の1個の肝細胞に認められる。

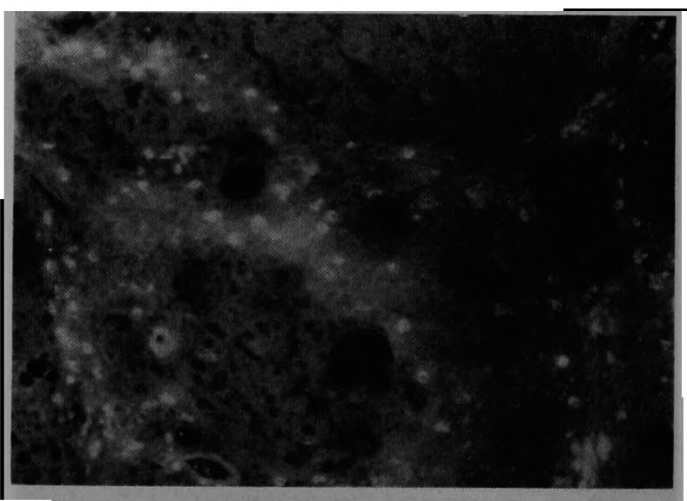

19. 四塩化岩素投与 8 邀(鳤光抗体直接法). 自己 抗体と考えられるグロブリッの特異䝁光は線䊒 性隔壁内の浸灌細胞之小葉内の 1 個の肝細胞に 認められる。

क $\because:$

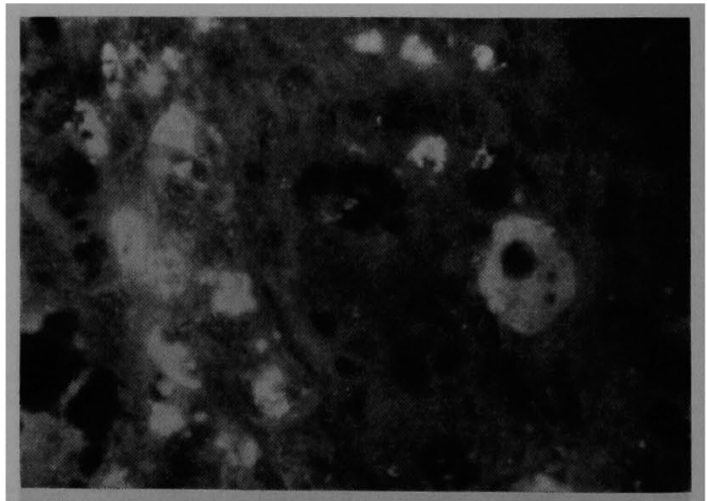

図 20. 四塩化岑案投与 8 週（临光抗体直接法）、四 19 の強扰大. 自己抗体と挎えられるグロブリ ンの特異螢光は線維性隔熊内扰よび小葉内の浸 潤と小莱内の 1 個の肝細胞に証められる. 


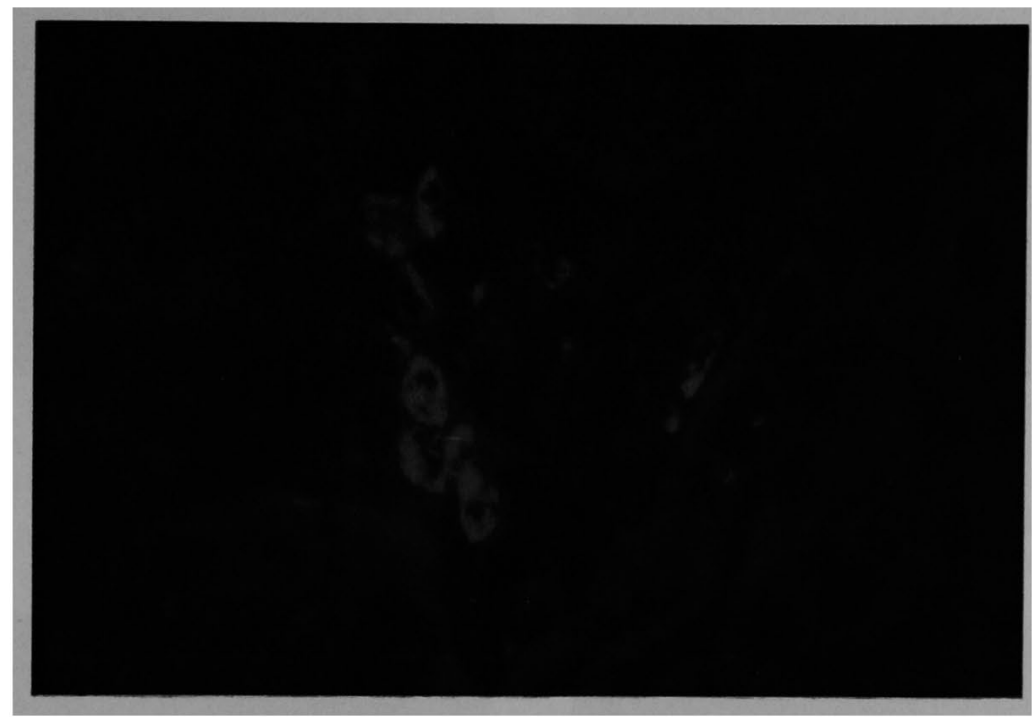

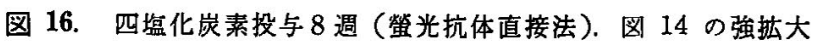

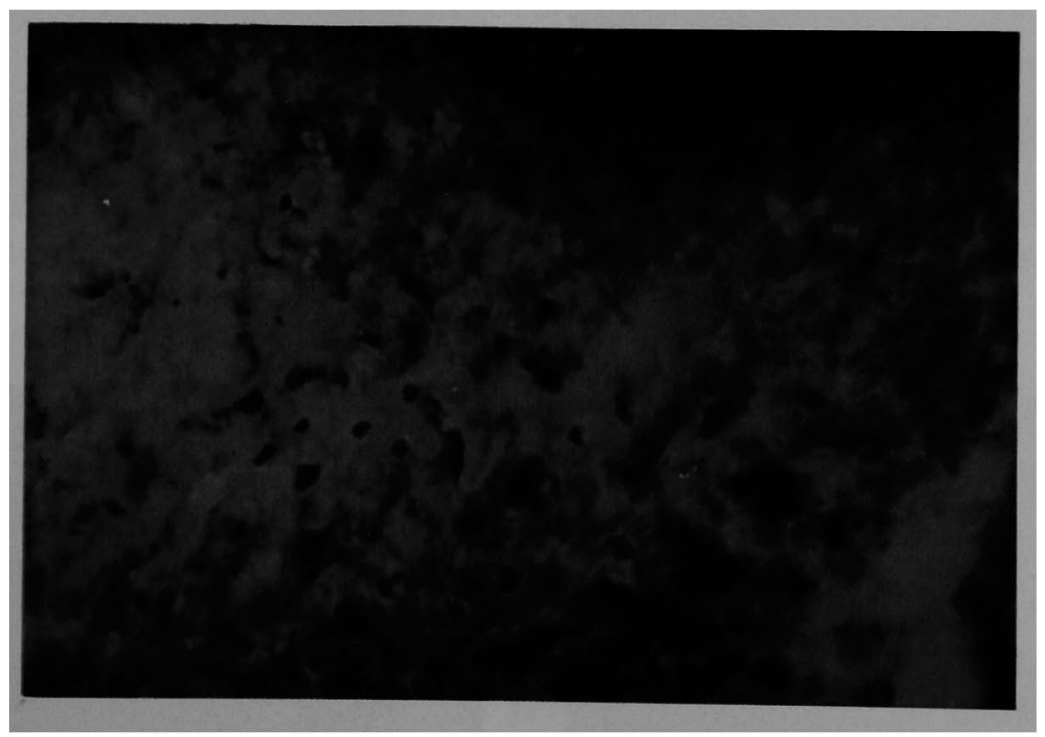

図 34. 症例 2(螢光抗体直接法)

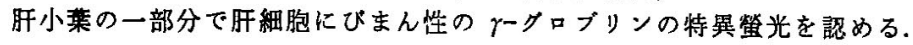




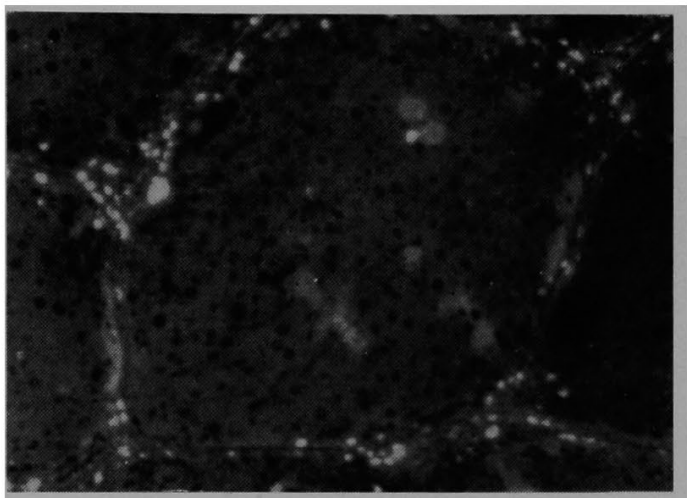

図 21. 四塩化炭素投与 8 週(蛨光抗体直接法). 自己 抗体と考えられるグロブリンの特異螢光は線維 生隔壁内の多数の浸泪細胞と小葉内の 1 個の浸 潤細胞および小集内と限界板の肝細胞飞認めら れる.

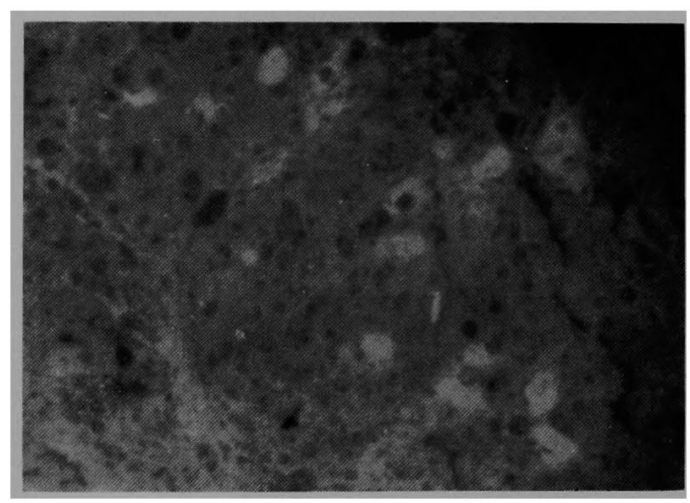

図 22. 溃光抗体直接法に上り肝細胞に証められたグ ロブリンの特異螢光

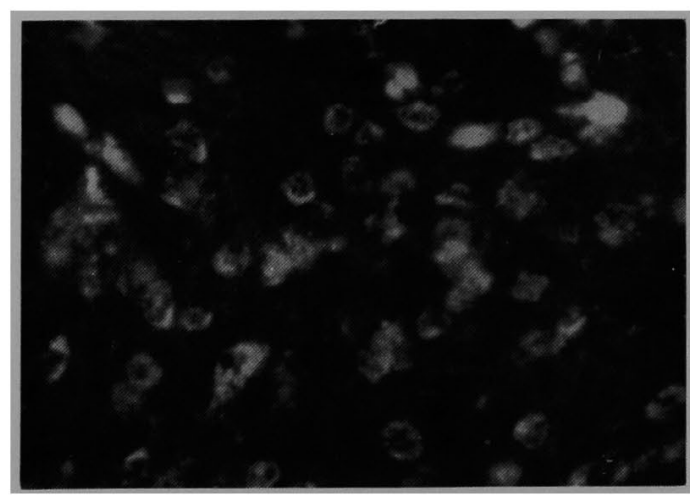

図 24. 策光抗体直接法により線維生隔壁内の骎潤細 胞に認められたグロブリンの特異䖝光
8 巻 4 号 (1967)

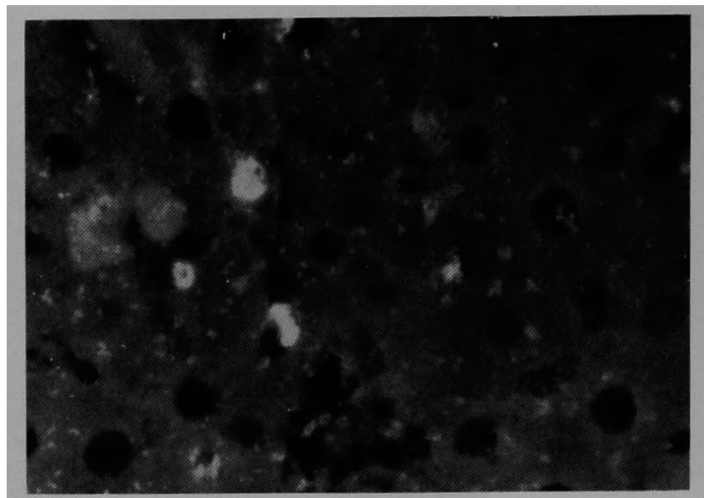

図 26. ブレドニンロン間歇併用 8 週（螢光抗体直接 法).グロプリンの特異䖝光は 2 個のクッペル 星勫胞と 1 個の小集内浸潤細胞に認的られる。

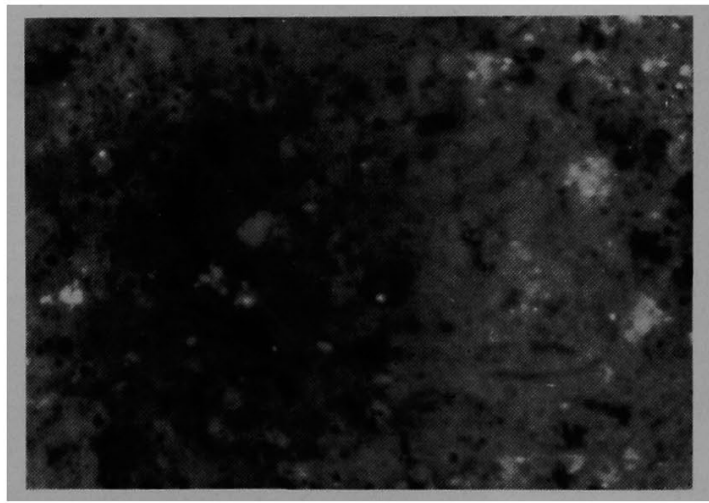

図 23. $\mathrm{pH} 3.3$ のクエン酸㣪衝液で前処瞋後螢光抗 体直接法を行な5と図22で認められたクロブ リンの特異踾光は認的られない。

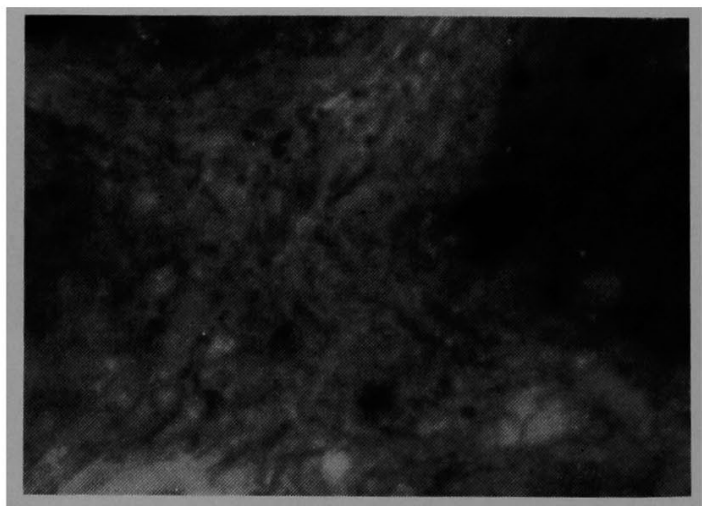

図 25. $\mathrm{pH} 3.3$ のクエン酸悢衙夜で前処置後螢光抗 体直接法を行なうと図 24 で認めら九たダロブ リンの特異螢光は認められない。 


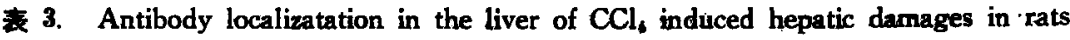

\begin{tabular}{|c|c|c|c|c|c|c|c|}
\hline \multirow{2}{*}{$\begin{array}{l}\text { Number } \\
\text { of Rat }\end{array}$} & \multirow{2}{*}{ Treatment } & \multirow{2}{*}{$\begin{array}{l}\text { Treatment } \\
\text { weeks }\end{array}$} & \multicolumn{2}{|c|}{ Hepatic cell } & \multirow{2}{*}{$\begin{array}{l}\text { Infiltrative } \\
\text { cell }\end{array}$} & \multirow{2}{*}{$\begin{array}{l}\text { Infiltrative } \\
\text { cell, and } \\
\text { hepatic cell } \\
\text { in lobule }\end{array}$} & \multirow{2}{*}{$\begin{array}{l}\text { Infiltrative } \\
\text { cell and } \\
\text { hepatic cell } \\
\text { in limiting } \\
\text { plate }\end{array}$} \\
\hline & & & in lobule & in limiting & & & \\
\hline $\begin{array}{l}1 \\
3 \\
1\end{array}$ & $\mathrm{CCl}_{4}^{\prime}$ (twice in a week) & $\begin{array}{l}4 \\
8 \\
9\end{array}$ & $\begin{array}{l}1 \\
1 . \\
1 .\end{array}$ & $\begin{array}{l}0 \\
0 \\
0\end{array}$ & $\begin{array}{l}0 \\
1 \\
0\end{array}$ & $\begin{array}{l}0 \\
1 * \\
0\end{array}$ & $\begin{array}{l}0 \\
1 * \\
0\end{array}$ \\
\hline $\begin{array}{l}3 \\
4\end{array}$ & $\begin{array}{l}\mathrm{CCl}_{4} \text { (twice in a week) with } \\
\text { prednisolone (every day) }\end{array}$ & $\begin{array}{l}4 \\
8\end{array}$ & $\begin{array}{l}0 \\
\mathbf{2}\end{array}$ & $\begin{array}{l}3 \\
1\end{array}$ & $\begin{array}{l}0 \\
1\end{array}$ & $\begin{array}{l}0 \\
0\end{array}$ & $\begin{array}{l}0 \\
0\end{array}$ \\
\hline $\begin{array}{l}2 \\
3\end{array}$ & $\begin{array}{l}\mathrm{OCl}_{4} \text { with prednisolone } \\
\text { (twice in a week) }\end{array}$ & $\begin{array}{l}4 \\
8\end{array}$ & $\begin{array}{l}2 \\
0\end{array}$ & $\begin{array}{l}0 \\
0\end{array}$ & $\begin{array}{l}0 \\
2\end{array}$ & $\begin{array}{l}0 \\
1\end{array}$ & $\stackrel{0}{0}$ \\
\hline 17 & Total & & 7 & 4 & 4 & 2 & 1 \\
\hline
\end{tabular}

および小葉内の単一の肝細胞にグロブリンを認めた.

これらの店例の速綄肝切片を pII 3.3 のクェン 酸䜌 街夜で前処置挠签光抗体直接法を施行すると，これらの クロブリンの特䖝光は認められないので，小葉内や限 界板の肝細胞および小葉内や線維珄隔集内の浸潤細胞に 認められたこれらのグロブリンは抗原抗体結合物の形で 存在していると考えられ，対応寸る抗原は不明であるが 細胸鈞着性抗体々推定された（因 $22 \sim 25)$.

図 26 はプンドニソロン間歇併用 8 週群の一例で, ク ッベル星細胞にグロブリンを摁めた.

次に組織抗体陽性と考えられる 17 例について，抗体 と推定されるグロブリンを認める細胞の局在を検討した 結果, 4 週群では四塩化炭素単独投与群 1 匹中 1 匹が小 葉内肝細胞, プレドニンロン毎日併用群 3 匹中 3 匹が限

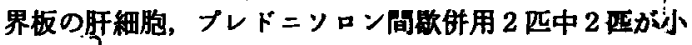

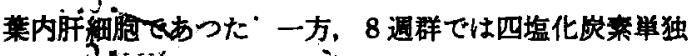

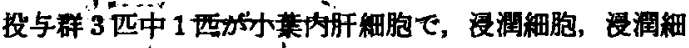
胞と小葉内肝緗胞, 漫阔細胞と小葉内および限界板の肝 細胞がおのおの 1 匹ずつであり，ブレドニンロン毎日併 用群 4 匹中 2 匹が小菜内肝細胞で，限界板の肝細胞，浸 潤細胞がおのおの 1 匹ずつであり，プレドニソロン間歇 併用群 3 匹中 2 匹が浸洞細胞，1匹が浸浧細胞と小葉内 肝細胞であつた．四塩化炭素単独投与 9 週群の 1 匹では 小葉内肝細胞であつた．以上，例数が少ないので結論は たせないが，4週群で性細胞に抗体性と推定されるグ

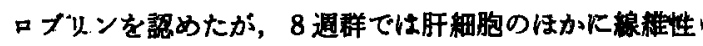
隔壁内および小葉内の浸潤細胞に抗体性と推定されるタ。 ロブリンを譛めた(表 3 ).

２）実跧.B）で流血中の抗体を追求する一方，抗
表 4. Incidence of localizing and circulating antiliver antibody in rats with $\mathrm{CCl}_{4}$ induced hepatic danages

\begin{tabular}{l|r|r|r|r} 
& Treetment & No. of & \multicolumn{2}{|c}{ Antibody in } \\
\cline { 3 - 5 } & weeks & Rat & Tissue & Serum \\
\hline & 2 & 3 & 0 & 0 \\
& 3 & 3 & 0 & 0 \\
& 4 & 11 & 7 & 2 \\
& 5 & 3 & 0 & 0 \\
& 6 & 3 & 0 & 0 \\
& 7 & 3 & 0 & 0 \\
\hline Total given & 8 & 10 & 5 & 5 \\
\hline No CCl given & $4 \sim 8$ & 10 & 0 & 0 \\
\hline Total & & 5 & 1 & 1 \\
\hline
\end{tabular}

原抗体結合物または細胞鈎着性抗体と推定されるグロブ リシンとの関連について検詂した(表 4 ).

その結果, 線䎦增生が軽度に認められる4週群 11 元 では，肝細胞に抗原抗体結合物または細胞鈎着性抗体と 推定されるグロブリンを認めるむの7匹，in vitro で正 常の同透ダイコクネズミ肝細胞の細胞質，ことに核周辺 部と強く結合する血清因子を認める すのが 2 匹であつ た. 倩小葉形成が認められる8週群 10 元では，肝細胞 に抗原抗体結合物または啝胞鈎着性执体と推定されるグ ロブリンを認めるむの 5 匹, in vitro で正常の同在ダィ コクネズミ肝細胞の细胞質,ことに核周辺部と強く結合 する血清因子を諗めるむのが5元であつた．9.遇群の 5 匹では，䀒細胞に抗原抗体結合物または細胞物着性抗体 
$8: 320$

肝

Put

と推定されるグロブリンを認めるもの1匹，in vitroで 正常の同種ダイコクネズミ肝細胞の細胞質,ことに核周 辺部と強く結合する血清因老認めるもの 1 匹であつた. これらの血清因子は， $\mathrm{pH} 3.3$ のクェン酸緩衝液で前処 置を行ならと血清因子（グロブリン）の特異篮光が認め られないので，抗体性であると推定された（困 27, 28).

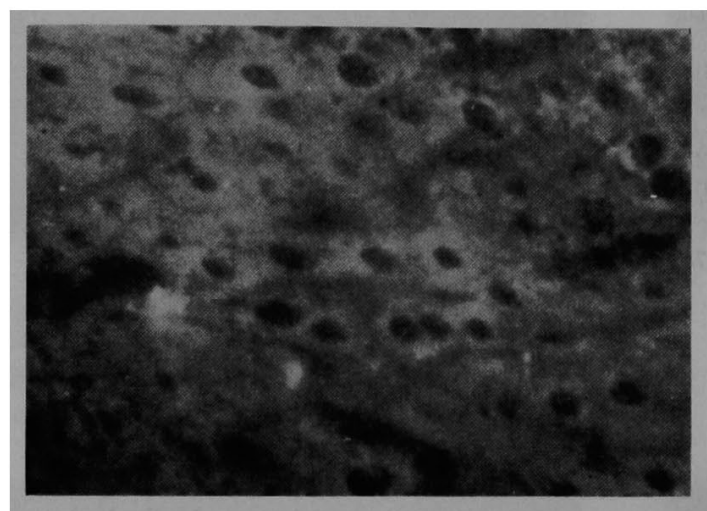

図 27. 四塩化炭素投与 8 週 (螢光抗体間接法). In vitro で正常同種肝の肝紏胞質ことに核周辺部 と強く絬合する血清因子を認めた。

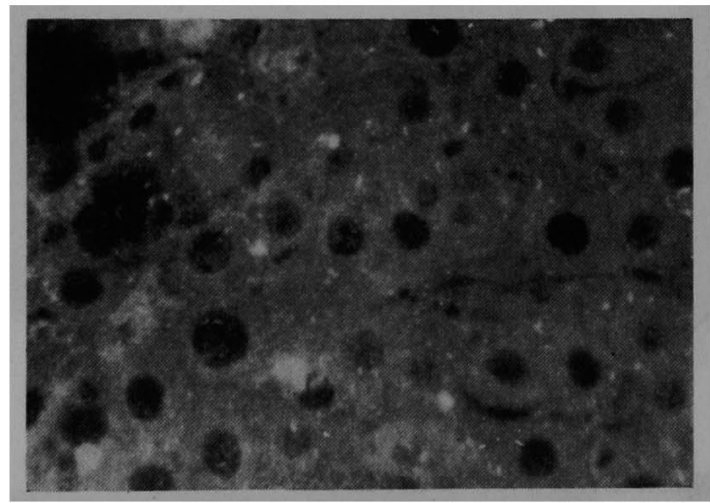

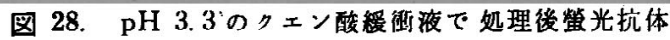
液を作用させると図 27 で訆められた血清因子 の特異䖝光は㒛められない。

肝細胞の抗原抗体結合物，または細胞鈎着性抗体と推 定されるグロブリンと抗体性と推定される血清因子とは 同時に検出される場合もあり，いずれか一方しか検出さ れない場合もあつた。四塩化炭素投与 $2,3,5,6,7$ 週の各群と無処置群では肝細胞の抗原抗体結合物, また は細胞銁着性抗体と推定されるグロブリンむ抗体性と推 定される血清因子も検出されなかつた。

3）実験 C）では四塩化㞸素一回投与後どのくらい で血清因子が娭出されるかを険討した(表 5).
8 巻 4 号 (1967)

表 5. Incidence of serum factor in rats with $\mathrm{CCl}_{4}$ induced hepatic damages

\begin{tabular}{l|r|r|c}
\hline & $\begin{array}{c}\text { Hours after } \\
\text { injection }\end{array}$ & No. of Rat & $\begin{array}{c}\text { Serum } \\
\text { factor }\end{array}$ \\
\hline & 24 & 5 & 4 \\
$\mathrm{CCl}_{4}$ given & 48 & 5 & 2 \\
& 92 & 5 & 0 \\
& 120 & 3 & 0 \\
\hline Total & & 22 & 6 \\
\hline No CCl, given & & 10 & 0 \\
\hline Total & & 32 & 6 \\
\hline
\end{tabular}

その絬果，投与後 "24 時間の 5 匹中 4 匹と” 48 時間の 5 匹゙中 2 匹に血清因子が検出された.ししかし，72時間の 5 匹，96時間の 4 匹，120時間の 3 匹，無処值の 10 匹 ではいずれも血清因子が検出されなかつた。

II. 臨 床 例

症例 1 : 斉○淑○，25 才，家婦，(困 29).

昭和 40 年 3 月10日子宮外妊娠で開腹手術を5けたが, 術中術後を通じて保存血 $1000 \mathrm{cc}$ を輸血された. 榆血後

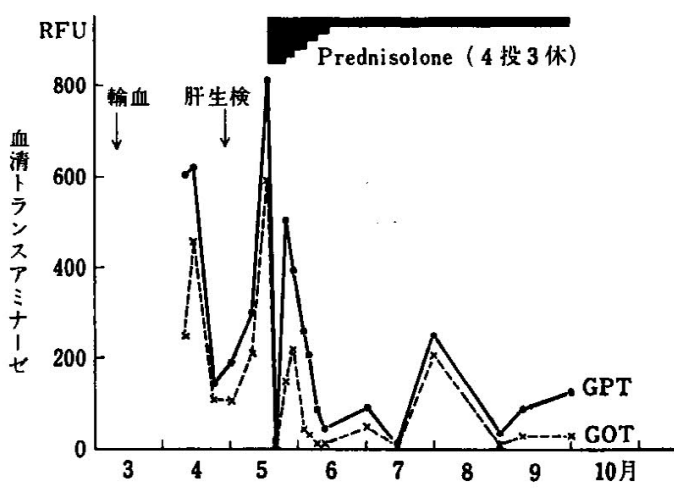

図 29. 症例 1 の serum transaminase の変動

約 30 日の 4 月 9 日ころより全身倦急感，食欲不振，悪 心あり，家人に黄庭を指摘された．心窝部圧迫感が時折 あり, 4 月 12 日某医受診, 血清総ビリルビン $4.1 \mathrm{mg} / \mathrm{dl}$, 血清 GPT 603 単位, GOT 250 単位, コリンェステラ 一ゼ活性（フコレスト法）は15 分であつた. 4 月 13 日 当内科外来受診，血清総 ビリルビン $3.5 \mathrm{mg} / d l$, 血清 GPT 637 単位, GOT 455 単位, 膠質反応は陰性であ つた４月 23 日当科入院.

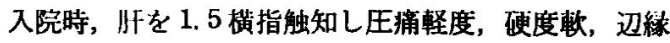
鈍，表面平滑であつた，血清 GPT 149 単位, GOT 124 
単位, ZTT 7.5, TTT 2.5, CCLF (-), 血清総ビリ ルビン $0.9 \mathrm{mg} / d l$, Latex 反応(ー)であつた. 肝庇護 剤の投与により漸次血清トランスフミナーゼ值の減少が 認められた. 5 月 6 日肝生検施行. 光䫓像ではグリンン 䩪の軽い細胞浸潤, 少数の好酸体, 星細胞の動員, 小葉 内の比校的集族性の細胞浸潤などを認めた（因 30).

䖝光抗体直接法では肝細胞之類洞腔内に，书そらくクッ ペル星細胞と思われる部位に 31). 5 月 10 日血清トランスフミナーゼ值は急上昇を示

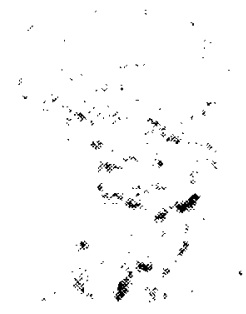

図 30.

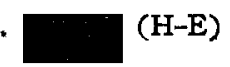

図 31. 症例 1 (煢光抗体直接法)

肝細胞と類洞腔内の細胞(おうらくクッベル星緗胞)

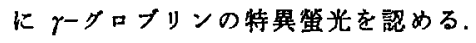

- L, GPT 302 単位, GOT 209 単位となつた. 5月 17 日食欲不振, 悪心あり, GPT 820 単位, GOT 590 単 位, 血清総ビリルビン $2.6 \mathrm{mg} / d l$, ZTT 7.0, TTT 3. 9, $\operatorname{CCLF}(-), \gamma$ グロブリン $17.2 \%$ で增覀の傾向 が認められたので, プドニソロン初期投与量 $30 \mathrm{mg} /$ day 4 投 3 休各週 $5 \mathrm{mg}$ の激減療法を実施したところ, 血清トランスアミナーゼ值は濑次下降し, 自覚症状の改 善肝腫脹の消失が認められ，6月12 日には血清トラン
スフミナーゼは, GPT 52 単位, GOT 32 単位となつ た. 6 月 16 日家人の希望もあり退院, プレドニソロン $5 \mathrm{mg} /$ day の維持量で外来治療を行なつている.

症例 $2: 川 \bigcirc \equiv O, 51$ 才, 家婦 (図 32).

昭和 40 年,2月 25 日乳癌のため当院外科で手術を5 けた，術中術後を通じて保存血 $2200 \mathrm{cc}$ の輸血をらけ，

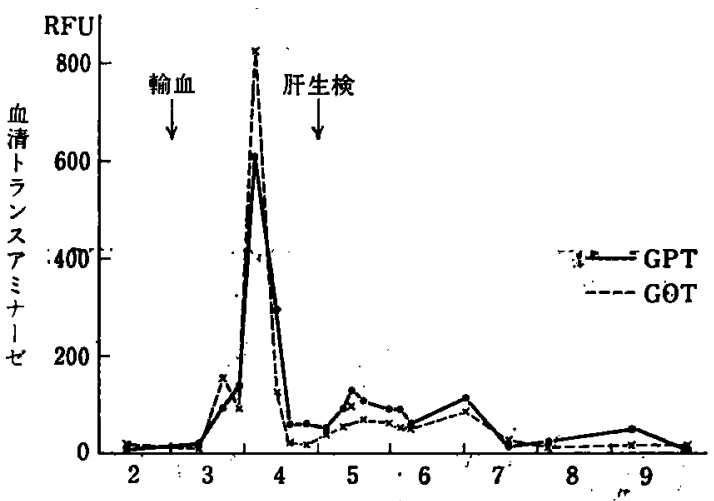

図 32. 应例 2 の serum transaminase $の$ 変動

3 月 1 日退院. 退院後全身隐怠感あり, 3 月 11 日の血清 GPT 14 単位, GOT 17 単位であつたが, 29 日.GPT 178 単位, GOT 94 単位となり, 4 月 3 日当内科外来受 診、肝は 2 横指触知し硬度軟で圧痛軽度であつた. 血清 GPT 615 単位, GOT 870 単位, 血清総ビリルビン 0.8 $\mathrm{mg} / d l$, TTT 1.1, ZTT 8.0, CCLF (-), r-グロブ リン $21.6 \%$ であつた. 4 月 13 日当科入院.

肝は1 横指触知し, 弾力性軟で圧痛なし, 血清 GPT 294 単位, GOT 130 単位, 血清総ビリルビン $0.6 \mathrm{mg} /$ $d l, \operatorname{TTT} 2.0, \operatorname{ZTT} 6.5, \operatorname{CCLF}(-), r$ グロブリン $21.2 \%$ であつだ. 4 月 19 日には血清 GPT 67 単位, GOT 39 単位となり，24 日肝生挨施行. 光顕像では肝 稩胞はかなり空胞化しており, 類洞に少数のリンハ様細 胞の浸潤を認めた（図 33）. 䖝光抗体直接法では，肝小 葉の一部分で肝細胞にびまん性の $r$ グロブリンの存在 を認めた（因 34)，4月 26 日血清 GPT 70 単位, GOT 32 単位, TTT 2.0, ZTT 5.9, CCLF (ー) であつた. 5 月 13 日食欲不振, 覀心あり, 14 日血清 GPT 149 単位, GOT 111 単位と上昇傾向がみられたが，31 日 GPT 84 単位, GOT 69 単位, 6 月 8 日退院. 外来で 経過観察中であるが， 7 月半ば以後, 血清 GPT, GOT は正常値にもどり，自覚的にも軽快した。

臨床例 66 例の肝切片について䖝光抗体直接法を用い て肝内の $\gamma$ グロブリンの存在を検討するとともに, 68 例 


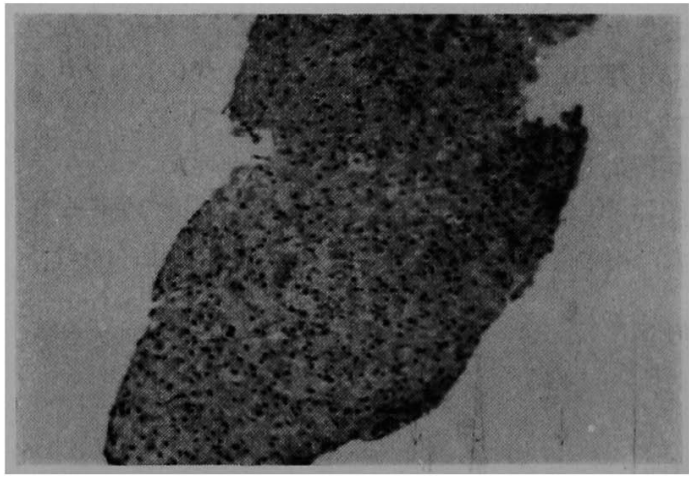

图 33. 症例 $2(\mathrm{H}-\mathrm{E})$

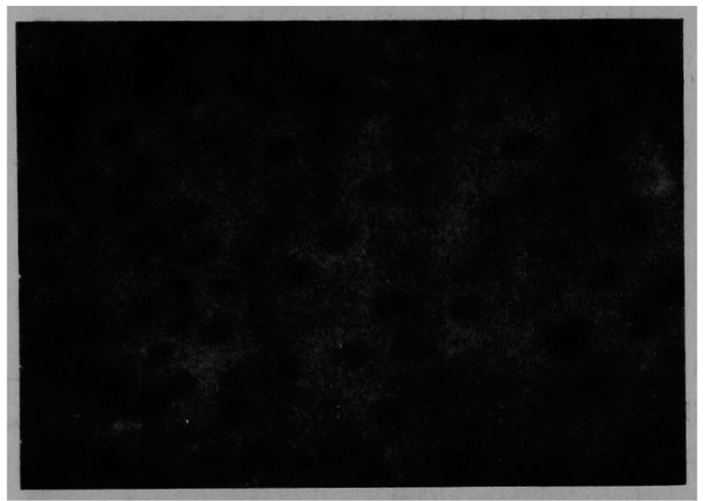

图 35. 慢性肝炎の症湖(螢光抗体間接法)，同種肝の 旰細胞啠，ことに核周辺部と結合ナる血情因子 を認めた。
8 巻 4 号 (1967) :

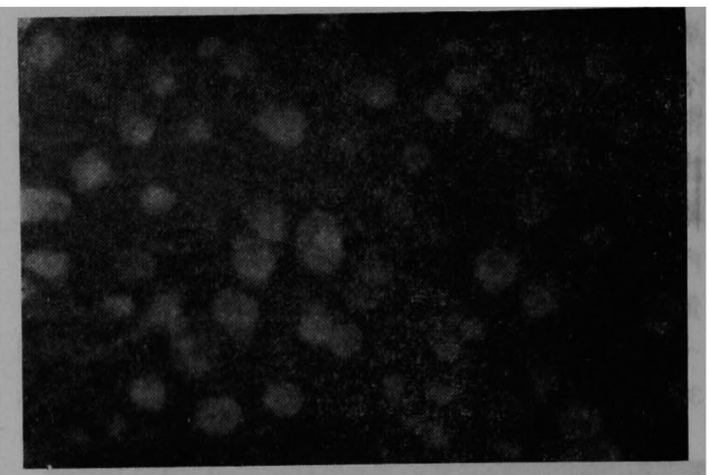

図 36. S. L.E. の叐例 (䖝光抗体間接法). 抗原に七 卜肝,ダイコクネスミ肝を用いて血中の抗核因 子を检出した。 胞の核にのみ認められる。

の血清について䖝光抗体間接法を用いて流血中の血清因 子の存在を検討した(表 6 ).

肝内 $r$ グロブリンは, 肝疾患 36 例では血清肝炎 8 例 中 4 例, 僈性肝炎 15 例中 1 例, 肝硬変 6 例中 3 例に検 出されたが，层染性肝炎 7 例では検出しえなかつた. 対 哭疾患 30 例では梅毒およびらつ血肝の 1 例で検出され たが, サルコイドーシスの 5 例, S. L. E., 二次性クワッ ショーカ一，発作性夜間血色素尿症の各 1 例，胃謴癌の 2 例, 胃癌の 19 例ではいずれる検出されなかつた。肝

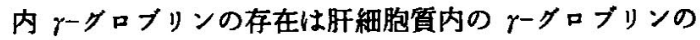
存在であつて，血清肝炎の 1 例ではおそらくクッペル星

表 6. Incidence of $\gamma$-globulin in the liver and serum factor in patients with various diseases

Diagnosis

Infections hepatitis

Serum hepatitis

Chronic hepatitis

Hepatic cirrhosis

Sarcoidosis

Systemic lupus erythematosus

Syphilis, engorged liver

Kwashiorkor syndrome

Common bile duct obstruction

Paroxysmal nocturnal hemoglobinuria

Gastric ulcer

Gastric cancer

\begin{tabular}{|c|c|c|c|}
\hline \multicolumn{2}{|c|}{$\gamma$-Grobulin in tissue } & \multicolumn{2}{|c|}{ Serum facter } \\
\hline $\begin{array}{l}\text { No. of } \\
\text { patient }\end{array}$ & $\begin{array}{c}\text { Positive } \\
\text { case }\end{array}$ & $\begin{array}{c}\text { No. of } \\
\text { patient }\end{array}$ & $\begin{array}{c}\text { Positive } \\
\text { case }\end{array}$ \\
\hline 7 & 0 & 7 & 0 \\
\hline 8 & 4 & 8 & 0 \\
\hline 15 & 1 & 15 & 1 \\
\hline 6 & 3 & 7 & 0 \\
\hline 5 & 0 & 5 & 0 \\
\hline 1 & 0 & 1 & 1 \\
\hline 1 & 1 & 1 & 0 \\
\hline \multirow[t]{2}{*}{1} & 0 & 1 & 0 \\
\hline & & 1 & 0 \\
\hline 1 & 0 & 1 & 0 \\
\hline 2 & 0 & 2 & 0 \\
\hline 19 & 0 & 19 & 0 \\
\hline
\end{tabular}


表 7. 症例

\begin{tabular}{|c|c|c|c|c|c|c|c|c|c|c|}
\hline \multirow{2}{*}{$\begin{array}{c}\text { Name of } \\
\text { patient }\end{array}$} & \multirow{2}{*}{$\begin{array}{l}\text { Clinicopathologic } \\
\text { diagnosis }\end{array}$} & \multirow{2}{*}{$\begin{array}{l}r \text {-Globulin } \\
\text { in hepatic } \\
\text { tissue }\end{array}$} & \multirow{2}{*}{$\begin{array}{l}\text { Serum } \\
\text { factor }\end{array}$} & \multicolumn{2}{|c|}{$\begin{array}{l}\text { Serum } \\
\text { ransaminase }\end{array}$} & \multirow{2}{*}{$\left|\begin{array}{c}\text { Serum } \\
\gamma-\text { globulin } \\
(\%)\end{array}\right|$} & \multicolumn{3}{|c|}{ Colloid reaction } & \multirow{2}{*}{$\begin{array}{l}\text { BSP } \\
(30 \mathrm{~min})\end{array}$} \\
\hline & & & & GOT & GPT & & ZTT & TTT & CCLF & \\
\hline I. T. & Acute hepatitis & $(-)$ & $(-)$ & 48 & 80 & 15.4 & 17.0 & 2.0 & $(-)$ & 7.5 \\
\hline K. S. & Acute hepatitis & $(-)$ & $(-)$ & 80 & 73 & 23.1 & 14.7 & 4. 1 & $(-)$ & 30.0 \\
\hline ,H. I . & Acute hepatitis & $(-)$ & $(-)$ & 20 & 43 & 15.6 & 7.0 & 1.5 & $(-)$ & \\
\hline Y.S. & Acute hepatitis & $(-)$ & $(-)$ & 21 & 31 & 24.2 & 1.6 & 1.0 & $(-)$ & 17.5 \\
\hline I. K. & Acute hepatitis & $(-)$ & $(-)$ & 23 & 18 & 16.5 & 7.5 & 4. 2 & $(-)$ & $15 \sim 17.5$ \\
\hline I. H. & Acute hepatitis & $(-)$ & $(-)$ & 16 & 18 & 17.5 & 5. 4 & 0.8 & $(-)$ & 10.0 \\
\hline A. S. & Acute hepatitis & $(-)$ & $(-)$ & 17 & 20 & 16.6 & 9.1 & 2.9 & $(-)$ & \\
\hline M. N. & Serum hepatitis & $(-)$ & $(-)$ & 47 & 37 & 29.3 & 10.5 & 2.6 & $(-)$ & 10.0 \\
\hline K. K. & Serum hepatitis & $(-)$ & $(-)$ & 420 & 408 & 22.8 & 11.0 & 6.0 & $(-)$ & \\
\hline $\mathbf{S} \cdot \mathbf{K}$. & Serum hepatitis & $(-)$ & $(-)$ & 38 & 32 & 22.6 & 3.1 & 1.0 & $(-)$ & 10.0 \\
\hline K. Y. & Serum hepatitis & $(-)$ & $(-)$ & 26 & 22 & 22.8 & 7.3 & 2.2 & $(-)$ & $7.5 \sim 10.0$ \\
\hline Y. K. & Serum hepatitis & $(+)$ & $(-)$ & 32 & 70 & 21.2 & 6.5 & 2.7 & $(-)$ & 10.0 \\
\hline Y. S. & Serum hepatitis & $(+)$ & $(-)$ & 94 & 820 & 17.2 & 6.5 & 3.4 & $(-)$ & 15.0 \\
\hline S. I. & Serum hepatitis & $(+)$ & $(-)$ & 43 & 46 & 20.0 & 8.0 & 1.5 & $(-)$ & 12.5 \\
\hline A. $T$. & Serum hepatitis & $(t)$ & $(-)$ & 41 & 22 & 22.0 & 13. 0 & 5.7 & $(-)$ & 5.0 \\
\hline $\mathbf{K} \cdot \mathbf{M}$. & Chronic hepatitis & $(-)$ & $(-)$ & 73 & 77 & & 8. 0 & 1.4 & $(-)$ & 7.5 \\
\hline Y.T. & Chronic hepatitis & $(-)$ & $(-)$ & & 84 & 21.0 & & & & \\
\hline I. S. & Chronic hepatitis & $(-)$ & $(-)$ & 17 & 27 & 16. 7 & 8.0 & 3.7 & $(-)$ & 15.0 \\
\hline D. S. & Chronic hepatitis & $(-)$ & $(-)$ & 69 & 49 & 33.4 & 19.4 & 7.6 & $(-)$ & \\
\hline $\mathbf{S} \cdot \mathbf{M}$. & Chronic hepatitis & $(-)$ & $(-)$ & & 10. 5 & 16. 7 & & & & \\
\hline K. S. & Chronic hepatitis & $(+)$ & $(-)$ & 35 & 29 & 27.9 & 19.4 & 10.7 & $(-)$ & $17.5 \sim 20.0$ \\
\hline I. Y . & Chronic hepatitis & $(-)$ & $(-)$ & 76 & 88 & 23. 2 & 22.1 & 8.6 & $(-)$ & 30.0 \\
\hline s. S. & $\begin{array}{l}\text { Chronic hepatitis } \\
\text { Diabetes mellitus }\end{array}$ & $(-)$ & $(-)$ & 62 & 66 & 32.7 & 19.7 & 8.4 & $(-)$ & 27.5 \\
\hline Y. I. & Chronic hepatitis & $(-)$ & $(+)$ & 193 & 93 & 10.2 & 9.5 & & $(-)$ & 10.0 \\
\hline T. W. & Chronic hepatitis & $(-)$ & $(-)$ & 37 & 76 & 23.8 & 4.5 & 3. 2 & $(-)$ & \\
\hline $\mathbf{I} \cdot \mathbf{N}$ & $\begin{array}{l}\text { Chronic hepatitis } \\
\text { Diabetes mellitus }\end{array}$ & $(-)$ & $(-)$ & 41 & 16 & 16. 7 & 9.6 & 3.5 & $(-)$ & 20.0 \\
\hline $\mathbf{T} \cdot \mathbf{K}$. & Chronic hepatitis & $(-)$ & $(-)$ & 94 & 72 & 31.9 & 16.1 & 4. 0 & $(-)$ & 7.5 \\
\hline $\mathbf{T} . \mathbf{N}$. & Chronic hepatitis & $(-)$ & $(-)$ & 120 & 140 & 21.7 & 9.4 & 1.2 & $(-)$ & 7.5 \\
\hline K. A. & Chronic hepatitis & $(-)$ & $(-)$ & 84 & 136 & 14.7 & 4. 7 & 3.6 & $(-)$ & 10.0 \\
\hline S. I. & Chronic hepatitis & $(-)$ & $(-)$ & & 25 & 21.6 & & & & \\
\hline M. O. & Hepatic cirrhosis & $(-)$ & $(-)$ & 108 & 108 & 18. 3 & 14.3 & 5.4 & $(-)$ & 15.0 \\
\hline M. I. & Hepatic cirrhosis & $(+)$ & $(-)$ & 31 & 25 & 21.2 & 9.1 & 1.6 & $(-)$ & \\
\hline A. K. & Hepatic cirrhosis & $(+)$ & $(-)$ & 77 & 95 & 17.5 & 11.5 & & $(-)$ & 30.0 \\
\hline Y. H. & Hepatic cirrhosis & $(+)$ & $(-)$ & 32 & 35 & 13.2 & 8.0 & 1.5 & $(-)$ & 12.5 \\
\hline S. T. & Hepatic cirrhosis & $(-)$ & $(-)$ & 32 & 31 & 26.5 & 10.3 & 2.8 & $(-)$ & 17.5 \\
\hline $\mathbf{M} \cdot \mathbf{N}$. & Hepatic cirrhosis & $(-)$ & $(-)$ & 56 & 52 & 28.4 & 14.6 & 4.2 & $(-)$ & 20.2 \\
\hline H. Y. & $\begin{array}{l}\text { Hepatic cirrhosis } \\
\text { Diabetes mellitus }\end{array}$ & & $(-)$ & 32 & & 29.2 & & & & \\
\hline $\mathbf{T} \cdot \mathbf{K}$. & $\begin{array}{l}\text { Syphilis, } \\
\text { engorged liver }\end{array}$ & $(+)$ & $(-)$ & 14 & 36 & 25.0 & 20.0 & & $(-)$ & 10.0 \\
\hline T. Z. & \begin{tabular}{|} 
Systemic lupus \\
erythematosus
\end{tabular} & & $(+)$ & & 22 & 13.9 & & & & \\
\hline
\end{tabular}


$8: 324$

肝

細胞と思われる部位にも $\gamma$-グロプリンを検出した。 流血中の血清因子は肝疾患 37 例では慢性肝炎 15 例 中 1 例錚出されたが，急性肝炎の 7 例，血清肝炎の 8 例，肝硬変の 7 例には検出されなかつた。この血清因子 は同種肝の肝細胞質核周辺部之結合する 血清 $\boldsymbol{\gamma}$-ダロブ リンである（因 35)，対照疾患 31 例では S.L.E.の 1 例で抗核因子を挨出したが（图 36），サルコイドーシス の 5 例，梅毒およびらつ血肝，二次性クロッショーカ 一, 総胆管閉塞, 発作性夜間血色尿症の各 1 例, 胃溃瘍 の 2 例, 胃癌の 19 例ではいずれる検出されなかつた.

肝疾患 37 例，梅毒およびうつ血肝，SLE の各 1 例， 計 39 例について肝内 $\gamma$-グロブリンと血清因子の 有無 血清トランスフミナーゼ，血清 $\gamma$-ダロブリン，筫反 応，BSP などについて検討した（表 7).

その結果, 肝内 $\gamma$-グロブリンや血清因子の 有無と臨 床検查所見との間には，とくに関連を見出すことはでき なかつた。

\section{繶括およひ考案}

肝疾患における血清トランスアミナーセ值の上昇は障 害された肝細胞から血中へのトランスフミナーゼの漏出 によるが，この場合，肝抗原の血中遊出も当然考えられ る.この観点から Espinosa ら"11はダイコクネズミに四 塩化炭素を注射し血中の抗肝原の推移を Ouchterlony 法 で検討した結果, 血中肝抗原は注射後 12 24 時間でピ 一クに達し，2 日後に下降線をたどるとしており， Pinckard 5 ${ }^{\text {s5) }}$ (四塩化炭素注射家鬼にみられる血中の 抗肝抗体は 1 gM にあり,これと反応する肝抗原はミ

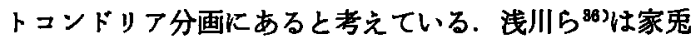
飞四塩化炭素投与後 6 12 時間加血中に肝抗原性物質 が証明され，3〜4 日で消失し，大体 GPT，GOT の消 長と平行しここれらの㱠素活性值が高値を示す間，陽性 像を呈するといらが，抗肝抗体の出現と肝抗原性物質の 間にとくに関連性はないと推測した。しかし，肝障害の ある時点では，肝抗原と抗肝抗体が血中に共存すること は当然考えられ，両者間に反応が起こるであるらことも 容易に推測される. したがつて抗原と抗体が最適比で存 在する区域をはさんで，抗原過鄱域と抗体過剩域が in vivo で生じていることも推定され血中の肝抗原性物質 と抗肝抗体の出現が必らずしも平行しないことはありう るであろ5。辛島ら ${ }^{87}$ は血中の抗肝抗体は七ト，牛，家 鬼等の肝組織とほぼ同程度に反応し，病肝と健康肝との 間にも差は認めがたいので本抗体の検出には同種また
8 巻 4 号 (1967)

は異種の肝組織を抗原として使用できるとのべている。 私は同種肝組織を抗原として動物実験々臨床例で血中 の抗肝抗体について螢光抗体間接法により検討した， そ の結果, 動物実殹では四塩化炭素注射後 24 時間と 48 時 間で血中に抗肝抗体と推定される血清因子を検出した。 Weir ${ }^{88)}$ はダイコクネズミに四塩化炭素注射後 $2 \sim 3$ 日 以内に補体結合反応淿より血中に抗肝抗体を梌出してい る. 私の実験と多少時間的なずれがあるが，四塩化炭素 の投与量が少ないことが一因と考えられる.

この血中の抗肝抗体は私の四塩化炭素によるダイコク ネズミ肝障害実験では，肝に結合織增生が軽度に認めら れる 4 週と，偽小葉形成が認められる8 週, 9 週の一部 の例にのみ証明され，また臨床例 39 例についての肝機 能と血中の抗肝抗体と推定される血清因子出現との検討 においても両者間にとくに関係は見出されず，本抗体の 病因作用については決定的なことはい光ない。

石井ら ${ }^{893}$ は肝疾患で肝細胞の崩壊等に上り肝乳郕上清 抗原の血中遊出が起これば，そこで血中自己抗体と反応 乙抗原抗体結合物が形成されて生物学的活性をえた後， 正常肝組織に鈎着すれば肝組織障害が起こりらるとして いる. Popper 5 40)は異種タンパクによる抗原抗体結合 物をダイコクネズミの胆管から注入し胆管周囲の急性炎 症, 肝細胞壊死, 次いで慢性炎症性变化等を観察して拉 ク, Paronetto ら (1)はマウスに四塩化炭素注射後異種タ ソパクによる抗原抗体結合物を注射して肝障害の增強さ れることを認めている.これは四塩化炭素により肝細胞 の透過性六進とクッペル星細胞の貪食能低下が起こるた め, 細胞障害性の抗原抗体結合物が肝細胞に沈着して既 存の四塩化炭素による䵊少障害巣を拡大するからとのべ ている. かかる観察より Popper は肝炎の慢性化には必 らずしも自己の肝起源の抗原とそれに対する抗体でなく とも，とにかく抗原抗体結合物ができれば，それが肝細 胞傷害性に働き軽微ながら傷害されている肝細胞はこの 抗原抗体結合物を取り込みやすいので，傷害が一層強く なるといつている. 山本 ${ }^{42}$ は Campbell の明黄感作によ る片腎茎結䇣ダイコクネズミの実験的肝硬变症で䖝光抗 体法により，グリソン螨，中心静脈付近，小葉内小壊死 巣に集族する主としてブラズ、様細胞からなる円形漫潤 細胞に ケーグロブリンを認めたが，变性塄死に宿つた肝細 胞には認めていない.太田 ${ }^{43}$ ) 臨床例に螢光抗体法を用 いて，障害された肝細胞に in vivo でダロブリン沈着の 有無を検討した結果，僈性肝桨 14 例に 1 例むなく，壊 死後性肝硬変症 9 例中 1 例, 肝癌を伴なつた肝硬変症 5 
例中 2 例に沈着を認めたが, elution procedure による 抗体の確認は行なつておらず，䖝光像や光顕像からこれ は単なる plasma imbibition とは考えられず, さりと て兔疫学的反応像とも決定しがたいとのべている. 以上

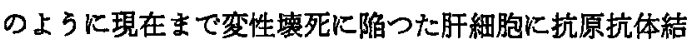
合物，または細胞鈎着性抗体としての自己グロブリンの 存在を認めたとの報告はない，私も䖝光抗体直接法によ $\eta$, 血清肝炎 4 例, 僈性肝炎 1 例, 肝硬変 3 例で肝細胞 に, 血清肝炎の 1 例ではクッベル星細胞に ンの存在を認めたが, elution procedure を実施しなか つたので抗体性のグロブリンか否かは確かでない，しか し，実呀的四塩化炭素肝障害ダイコクネズミで，小葉内 肝細胞, 限界板肝細胞, 線維性隔壁内の漫潤細胞にグロ ブリンの存在を認め, $\mathrm{pH} 3.3$ のクエン酸綏衙液で前処 直後管光抗体直接法を実施するとグロブリンの特異䖝光 がみられないので，抗原は検索していないため不明であ るが,とにかくこれらのグロブリンは抗原抗体結合物の 形で存在しているものと推定した，なお，線維性隔壁内 の浸潤細胞にグロブリンが認められるにもかかからず肝 細胞に証明されなかつたり，線維性隔壁内の漫潤細胞に 認められないにもかかわらず小葉内の肝細胞にダロブリ ンをみるものもあつて，線維性隔壁内の浸潤細胞で産生 された抗体性ダロブリンが肝細胞と結びついて障害作用 を発揮しているといら所見はえられなかつた。

Popper (4), Cohen 5 (5) 4 肝炎拉よび活動性肝硬変症, または塤死後性肝硬变症の肝で螢光抗体法を用い, 線維 性隔壁内中類洞内の網内系細胸に $r$ グロブリンを認め, ブラズマ細胞に移行しつつある 絧内系細胞が $\boldsymbol{\gamma}$ グロブ リンを産生しており，肝障害と免疫反応闪関保する肝内 浸潤紐胞の密度とはほは平行するとのべている. Gonza-

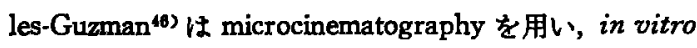
で immunoallergic shock の結果, 網内系細胞が形質細 胞に移行することを証明した．しかし，私の実験的四塩 化炭素ラット肝硬变症では䖝光抗体法により抗体性之考 えられるクロブリンが検出されない，すなわら免疫反応 に関係がないと思われる肝内浸潤細胞が存在する例むみ られるので, Burnet の immunologically competent cell が少なくとも肝障害の主要な促進因子とは考えられな い.また, 私の実験的四塩化炭素ラット肝硬変症では, 肝細胞にみられたグロブリンの特異篮光と浸潤細胞にみ られたそれでは強さに明らかな差があり，旰細胞で弱い といらことはなにを物語るものであろらか. 浸潤細胞で はグロブリソの積極的な産生があり，おそらく領食され
た肝抗原と紏胞質内て結合を起こしているが，肝細胞で は，産生されかつ血中に遊出した抗肝抗体(クロロブリン) が肝細胞質内の肝抗原と結合するが，障害肝細胞内の抗 原量は刻々と隇少しつつあるので，抗ダイコクネズミク ロブリン䖝光色素標識鬼グロブリンが比較的結合しにく いためであろらと推定している.

自己免疫疾患における本質的な病理学的所見について は議論があるが, Waksman473 はツベルクリン反応，移 植免疫, 実験的甲状腺炎等の病理組織所見を比較検討 し，本質的で共通な変化はびまん性または散在性のリン ×球および形質細胞の浸潤であろうとのべている. しか し一般的には，これらの細胞浸潤を僈性の炎症や組織の 崩壊に対する非特異的反応にすぎないと考える習慣があ る. 私の四塩化炭素ダイコクネズミ肝硬变症では，浸潤 細胞が免度学的に活動状態を示寸例があり，Scheiffarth ら ${ }^{25}$ ) は急性肝炎の 1 例，僈性肝炎の 2 例の肝切片を䖝光 色素標識同種肝細胞分割で染色し, 門脈周辺部の単核細 胞とクッペル星細胞に特異䖝光を認めており，これらの 細胞の活動状態は自己の体成分に対応するものであると 推定される. Mackay48) はルポイド肝炎の肝組織に芽中 心をもつたリンバ濾胞形成を認め，小坂ら (9)はウイルス

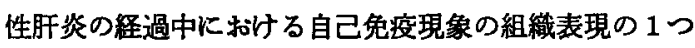
として濾胞性肝炎といら名称を提昌している. しかし, 市田ら ${ }^{50}$ 511 は活動性慢性肝炎の 38\% に lymphoid focus を証明したが，非活動性慢性肝焱の $40 \%$ にむlymphoid focus を認めたことから， lymphoid focus の存在のみ によつて活動性慢性肝炎とするにはなお多くの問題があ るとしている. 私の四塩化炭素ダイコクネズミ肝硬变症 ではその経過中に芽中心をもつたりンパ演胞形成の例は 認められなかつた. 一方, Schaffner $5^{52)}$, Popper(4)ら Kalk ${ }^{58}$ ( 肚硬变が進行性である場合飞再生結節周辺に piecemeal necrosis が発生することからこれを hepatic self perpetuation の組織学的表現として重要視し，䖝光 抗体法でこの部分に ケーグロブリン含有細胞が 豊富に出 現しているのを認めているが，肝壊死細胞には $\boldsymbol{r}$ ーダ口 ブリンを認めていないので, 壊死が抗原抗体反応の産物 であるといら証拠を欠いている.この点, 私の実験的ダ イコクネズミ肝硬変症に和ける結果は興味ある所見で, 障害された肝細胞に自己のグロブリンの存在を認め,こ れは抗体性のグロブリンであろらと推定した。

ステロイドホルモンとフレルギー反応との関連につい て,ステロイドホルモンは抗体産生, 抗原抗体反応を抑

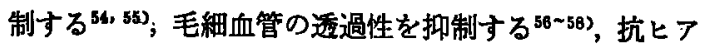


ルロニダーゼ作用を有する(59)といわれている. 畔柳ら は実釦的アレルギー性肝炎でプレドニンロンは抗肝抗体 中に含まれる localizing antibody の肝への局在を抑制 しないが, 抗肝抗体注射による白ネズミのアレルギー性 肝炎を抑制するとのべている. 私の奏験的ダイコクネズ ミ肝硬変症で, プレドニソロン併用群にも肝細胞に自己 グロブリンの存在を認めるものがあり，この点興味深 W.

肝炎の慢性化に自己免疫機転が穦極的に関与している と寸れば, 高率に，乙かも広範囲にわたつて細胞鉤着性 抗体が証明されるべきであるのに，私の実験的ダイコク ネズミ肝硬変症では低率，かつ散在性にしか証明されな いことから，自己免废機転が実験的四塩化崖素ダイュク ネズミ肝障害の慢性化に重要な役割を演じているとの結 論は引出せなかつた. しかし、リンパ球, 形質細胞を担 体とした細胞鈎着性抗体が肝実質細胞に障害因子として 作用することも推定され，肝炎の慢性化に遅延型過敏反 応または cell-bound immunity の面からの検討が今後さ らに必要であろ5.

\section{結 語}

肝炎の慢性化に対する自己免疫機転の関与を検 討する目的で, Coons の螢光抗体法の変法を用 いて，四塩化炭素ダイコクネズミ肝障害について 免疫細胞化学的検討を行なつた．同時に，臨床例 68 例（血清肝炎 8 例，急性肝炎 7 例，慢性肝炎 15 例, 肝硬变 7 例, 発作性夜間血色素尿症 1 例, サルコイドーシス 5 例， S. L.E. 1 例，梅毒拈よ びうつ血肝 1 例, 二次性クワッショーカー 1 例, 胃漬瑝 2 例，胃癌 19 例）についても同様の検討 を行なつた，その結果，次の所見をえた.

1）ダイコクネズミに四塩化炭素 $0.075 \mathrm{mg} /$ $100 \mathrm{~g}$ 体重を筋注すると，䖝光抗体間接法で，注 射後 24 時間之 48 時間で正常同種肝の肝細胞質 核周辺部と結合する血清因子が検出される例があ つた. 注射後 72 時間，96 時間， 120 時間では検 出されなかつた。

2）ダイコクネズミに四塩化炭素 $0.075 \mathrm{mg}$ / $100 \mathrm{~g}$ 体重を毎週 2 回筋注すると，線維增生が軽 度に認められる 4 週では，䖝光抗体間接法で正常 同種肝の肝細胞質ことに核周辺部と強く結合する
8 巻 4 号 (1967)

血清因子が検出される例があり，一方，䖝光抗体 直接法では障害された肝細胞の細胞質に自己グロ ブリンの存在する例を認めだ偽小葉形成が認め られる 8 週と 9 週では，䖝光抗体間接法で正常同 種肝の肝細胞質ことに核周辺と強く結合する血清 因子が検出される例があり，一方螢光抗体值接法 では障害された肝細胞と小葉内扣よび線維性隔壁 内の浸潤細胞の細胞質に自己グロブリンの存在す る例を認めた。また，8週の1例ではクッペル星 細胞に自己グロブリンの存在を認めた。

3）上述の血清因子は自己の血清中に存在する グロブリンであつて, $\mathrm{pH} 3.3$ のクエン酸緩衝液 で前処置を行ならと血清因子の特異螢光が認めら れないので，これらの血清因子は in vitro で正 常同種肝の肝細胞質ことに核周辺部之抗原抗体結 合を行なつていると推定された１）で検出され た血清因子については elution procedure を施行 しなからた.

4）肝細胞と小葉内および線維性隔壁内の浸潤 細胞に検出されたグロブリンは， $\mathrm{pH} 3.3$ のクエ ン酸緩衝夜で前処厧後䖝光体直接法を行なら之特 異螢光として認められなくなることから，in vivo で抗原抗体結合物の形で存在していると推定され た.

5）抗原抗体結合物の形で存在すると推定され るあるいは細胞鈎着性抗体と推定される肝細胞質 グロブリンは，小葉内の単一の肝細胞，限界板の 肝細胞に認められた。

6）プレドニソロン投与では，四塩化炭素ダイ コクネズミ肝障害時の肝内グロブリンの局在を抑 制することのできない例があつた。

7）臨床的には，血清肝炎 4 例，慢性 肝炎 1 例, 肝硬变 3 例で生検肝の肝細胞質に, 䖝光抗体 直接法によつて自己 $\gamma$-グロブリンの存在を認め た. 血清肝炎の 1 例では，クッベル星細胞に自己 rーグロブリンの存在を認めた．慢性肝炎の 1 例で は䖝光抗体間接法によつて正常同種肝の肝細胞質 ことに核周辺部と強く結合する血清因子（ $\gamma$-グロ ブリン) が検出された.

8）肝疾患 37 例，梅毒およびうつ血肝と SLE 
の各 1 例, 計 39 例について肝内 $r$-グロブリン および血清因子の存在と肝機能 (BSP, TTT, ZTT, CCLF, GOT, GPT) おょび血清 $\gamma$-グロ ブリン值との関係について検討したがとくに関連 を見出すことはできなかつた．しかし，実験的四 塩化炭素ダイコクネズミ肝硬変では, 肝組織内に 抗原抗体結合物の形で存在すると推定される。 たは細胞鈎着性抗体として存在すると推定される グロブリンと循環抗体と推定される血清因子が線 維增生や偽小葉形成となんらかの関連をむつて出 現するむのと推定された.

9）四塩化炭素ダイコクネズミ肝硬変で検出さ れた細胞鉤着性抗体と推定されるグロブリンと循 環抗体と推定される血清因子（グロプリン）と の同一性については, in vivo と in vitro での差 はあるが，螢光抗体法による染色態度に差が認め られるので，若干の異類性が推定された。

10）肝炎から肝硬変への経過中に自己グロブリ ンの肝細胞への鈎着が起こり，このグロブリンは 抗体としての性状を有するので肝焱の慢性化に自 己免疫機転の存在が推察された。

稿を格わるに臨み，ご指導，こ校閲を賜わつた恩師木 下康民教授に梁甚なる感碀の意を表するとともに，直接 こ指導を喑わった木下内科笹川力講師, 病理学数室木原 達博土, 金沢大学太田五六助教授に梁く感謝する.また, ご指導，こ協力をいただいた木下内科肝睡研究班各位に 梁く感謝する。

\section{文倖}

1) Witebsky, E., Rose, N. R., Terplan, K., Paine, J. R., \& Eagan, R. W.: JAMA, 164 : 1439, 1957. 2) Hughes, T. P. : J. Immun., $25: 275,1933 . \quad 3)$ Eaton, M. D., Murphy, W. D., \& Hanford, V. L. : J. Exp. Med., 79 : 539, $1944 . \quad$ 4) Bj $\phi$ rneboe, M., \& Krag, P. : Acta. Path. Microbiol. Scand., 24 : 352, 1947.

5) Miles, J. A. R. : Brit. J. Exp. Path., $27: 25,1946$. 6) Vorländer, K. O.: Z. Ges. Exp. Med., $118: 352$, 1962. 7) Gajdusek, D. C.: Arch. Intern. Med., $103: 9,1958 . \quad 8)$ Gökcen, M. : J. Lab. Clin. Med., $59: 533,1962 . \quad$ 9) Mackay, I. R. \& Larkin, L. : Aust. Ann. Med., 7 : 251, 1958.
R. \& Larkin, L. : Clin. Sci., 18 : 425, 1959.

Hackett, E., Beech, M. \& Forbes, I. J. : Brit. Med. J., II : 17, 1960. 12) Coppo, M., Tedeshi, G. \& Robbá, L.: Gastroenterologia, 2 : 1964 (文献 61 上り引用). 13) Olitzki, L. \& Bernkopf, H. : J. Infect. Dis., 77 : 60, 1945.114$)$ Mori, W., \& Suzuta, T. : Nature, $192: 41,1961 . \quad$ 15) Scheiffarth, F. \& Berg, G. : Klin. Wschr., $31: 441,1953 . \quad 16)$ Scheiffarth, F., Frenger, W. \& Brichzy, W.: Klin. Wschr., 33 : 445, 1955. 17) Asherson, G. L. \& Broberger, O.: Brit. Med. J., I : 1429, $1961 . \quad 18)$ Dausset, J. \& Marchall, G. : Immunopathologie, 1st. Internat. Symposion. Basel. Benno. Schwabe. \& Co., Basel. u Stuttgart., P. 113, 1959. 19）金田平：阪市大医誌, $9: 239,1960$.

20）辛島喜広: 服市大医誌, $7: 429,1958.21 ） \mathrm{Hu}$ nter, F. M., Sparks, R. D. \& Salzman, R. T. : Gastroenterology, $39: 394,1960.22$ 2) Henning, $N$., Scheiffarth, F. \& Warnatz, H. : Gastroenterologia, 1 : 221, $1963 . \quad$ 23) Paronetto, F., Schaffner, F. \& Popper, H. : Proc. Soc. Exp. Biol. Med., 106 : 216, 1961. 24) Paronetto, F.., Schaffner, F., Mutter, R. D., Kniffen, J. C. \& Popper, H. : JAMA, 187 : 503, 1964.

25) Scheiffarth, F., Warnatz, H., \& Essing, H. : Int. Arch. Allerg., 28 : 240, 1965.26 ) 小川勝土, 辻孝 夫, 太田康平: 旰䑏, $6: 263,1965.27$ ) 上田英雄, 重田治男, 山口潜, 小宮正女: 内科, $12: 450,1963$. 28）長島秀夫：日新医学, $48: 571,1961.29)$ 鈴木 秀郎：自己兔度上自己免矣患, 中外医学社, 東京, 初 斦, 105 頁, 1965. 30) Coons, A. H. \& Kaplan, M. H. : J. Exp. Med., $91: 1,1950 . \quad$ 31) Coons, A. H., Leduc, E. H. \& Connolly, J. M. : J. Exp. Med., $102: 49,1955.32)$ 川村明義, 川島䡒作, 塩入康平 : 最新医学, $17: 2739,1962.33$ 3) Freedman, P., Peters, J. H. \& Kark, R. M. : Arch. Intern. Med., 105 : 524, $1960 . \quad 34)$ Espinosa, E. \& Insunza, I. : Proc. Soc. Exp. Biol. Med., 111 : 174, $1962 . \quad$ 35) Pinckard, P. N. \& Weir, D. M. : Clin. Exp. Immunol,, 1 : 33, 1966. 36）浅川英男，奥田正治，大態信也，穴戸英 雄：フレルギー, $15: 28,1966.37)$ 辛島言広, 井神 宏: 日本臨牀, $22: 39,1964.38$ ) Weir, D M.： Immunology, 6 : 581, 1963. 39) 石井梁, 山本祐夫: 日内会誌, $51: 734,1962.40)$ Popper, $\mathrm{H}:$ 肝䁃, $3: 78,1961 . \quad$ 41) Paronetto, F. \& Popper, H. : 
8 巻 4 号 (1967)

Amer. J. Path., $47: 549,1965.42)$ 山本祐夫 : フレ ルギー，14:149，1965. 43) 太田五六 : 肝臓, 5 : 151, 1964. 44) Popper, H., Paronetto, F., \& Rubin, E. : Aktuelle Probleme der Hepatologie, Martini, Stuttgart, 1962. 45) Cohen, S., Ohta, G., Singer, E. J. \& Popper, H. : J. Exp. Med., 111 : 285, 1960. 46) Gonzales-Guzman, I. : Blood, 14 : 978, 1959.

47）鈴木秀郎：自己免疫と自己免疫疾患, 中外医学社, 東京, 初版, 141 面, 1965. 48) Mackay, I. R. \& Burnet, F. M. : Autoimmune Disease, C. C. Thomas Co., Illinois, 2nd ed.. p. 197, 1964 . 49) 小坂淳夫, 太 田康幸：肝嗒， $6: 284,1965.50$ ) Ichida, F., Sasaki, H. \&Wakisaka, G.: Progress in Liver Disease (ed. by Popper, H. \& Schaffner, F.), Grune \& Stratton, New York, Vol. 2, p. 416, 1965.51$)$ 市田文弘, 馬 庭熙, 中川忠幸, 井上巷一, 渡辺和雄, 葛岡哲男, 小川

弘道, 田中裕：日本臨牀, $24: 14,1966$, 52) Schaffner, F., Popper, H. \& de la Torre, M. : Gastroenterology, $30: 357,1956 . \quad 53)$ Kalk, H. : Verh. Deutsch. Ges. Inn. Med., $63: 177,1957 . \quad 54)$ Germuth, F. G., Ottinger, B. \& Oyama, J. : Proc. Soc. Exp. Biol. Med., 80 : 188, 1952 . 55) Germuth, F. G. : J. Exp. Med., $98:$ I, 1953. 56) Moon, V. H. \& Tershakovec, G. A. : Proc. Soc. Exp. Biol. Med., 79 : 63, 1952. 57) Chappel, J. W., Ebert, R. H. \& Barkley, W. R. : J. Lab. Clin. Med., 39 : 896, 1952.

58) 畔柳武雄 : 臨牀フレルギー, 医学書院, 東京, 1956. 59) Rawling, A. G. : Ann. Allerg., $10: 440,1952.60)$ 畔柳 武雄, 栗栖明, 杉山始, 紊藤昌信: 日新医学, $49: 458$, 1962. 61) Scheiffarth, F. \& Warnatz, H. : Klin. Wschr., 43 : 473, 1965.

第回 2 日本肝蓝学会西日本支部会ご案内

第 2 回日本肝臓学会西日本支部会を下記のごとく行な5予定ですの でご案内申しあげます

会 長 小坂淳夫教授 (岡山大学)

会 場 岡山市立市民会館

会 期 昭和 43 年1月 20 日（土）,21日（日）

$$
\text { [プログ ラ ム }
$$

特別講演

日本住血吸虫症中島敏郎教授（久留米医大）

パネル

肝搭と免疫

C. P. C.

一般演題

1）食道静脈瘁とその治療

2) 肝疾患と楉代謝

3) 原発性肝癌 